\title{
Transformation of the real estate and construction industry: empirical findings from Germany
}

\author{
Andreas Pfnür ${ }^{1} \cdot$ Benjamin Wagner ${ }^{1}$
}

Published online: 10 March 2020

(c) The Author(s) 2020

\begin{abstract}
The German real estate and construction industry is facing a transformation, triggered by fundamental changes in technology, the economy and society. The purpose of this paper is to explore how these changes exert pressure to adapt on existing business models, while also offering opportunities for their further development. A model that attributes the transformation of the real estate industry to megatrends, specific structural change drivers, business models and the interaction of the groups of players in the value creation system is developed. The model is tested empirically by a survey. Structural equation modelling is used to measure the impact of various determinants of transformation and the relevance of adaptation strategies to the different groups of players. As a result, the study explains three impact mechanisms of the transformation in the real estate industry. The transformation originates from the occupiers, who need more flexible space and are focusing on holistic solutions that are not provided by the real estate industry. Service providers are striving to increase the efficiency of their traditional processes, rather than evolving new business models or services. The investors recognise the increasing importance of the occupiers but they are rarely pursuing the resulting strategies. Property developers recognise these requirements: their adaptation strategies most strongly question their previous business. For practitioners, the results point out the opportunities and risks of transformation and help to illustrate the need for change. For academicians, the results indicate a way to explain and measure the transformation of a value creation system.
\end{abstract}

Keywords Real estate management $\cdot$ Real estate transformation $\cdot$ Structural change . Strategic management $\cdot$ Real estate trends

JEL Classification $\mathrm{R} 30 \cdot \mathrm{O} 33 \cdot \mathrm{Z} 10$

Benjamin Wagner

wagner@bwl.tu-darmstadt.de

1 Chair of Real Estate and Construction Management, Department of Law and Economics, Technische Universität Darmstadt, Hochschulstrasse 1, 64289 Darmstadt, Germany 


\section{Introduction}

The real estate industry in general and its business models in particular are facing a transformation, caused by fundamental changes in technology, economy and society. The impending transformation process results from structural change. At congresses, meetings, conferences and particularly in practice-oriented management studies, megatrends such as digitalisation, urbanisation, globalisation, sustainability and even socio-demographic change, as well as more specific drivers of structural change, are being widely discussed (e.g. Zeitner and Peyinghaus 2014; Baumanns et al. 2016; Weber 2017; Saiz and Salazar 2017). Compared to its practical relevance, there is scanty academic research on this topic. The focus of the present paper is on analysis of these change processes with regard to corporate practice and little emphasis on research trends. Change processes are strategically important for long-term decisions made by market participants in a value creation system. While long-term changes put existing business models under adjustment pressure, they also offer considerable market growth potential and create opportunities for the strategic development and/or enhancement of business models.

The initial effects of these change processes are becoming evident at widely differing levels. For instance, research shows that large companies are reducing the amount of space they occupy and are increasingly seeking accommodation on short-term leases, rather than owning self-occupied space (Just et al. 2017a). Particularly in the retail and logistics sector, the changing demand for space is already perceptible, as are the changes in office concepts that are taking effect (Feld et al. 2017). Far-reaching changes are foreseeable in the capital market with regard to real estate investments. For instance, opportunities for real estate financing are growing because of the enabling technologies of digitalisation and the increase in globalisation. Digital technologies promise increases in effectiveness and efficiency in the areas of design, construction, operation and utilisation. A steadily intensifying shortage of skilled workers is also foreseeable. These issues illustrate the breadth and depth to which structural change is currently beginning to affect the value creation system of the German real estate industry. However, a great deal of uncertainty remains about the actual effects and the impact mechanisms of this transformation. Currently, the management of German real estate companies is only in a position to adapt business models, products and services or processes if the overall effects of the change processes can be anticipated. To do so, the drivers of structural change must be identified and the impact mechanisms of transformation discerned.

Structural change is not a new phenomenon, though its manifestations are changing. Although it was introduced to scientific research many years ago (Schumpeter 1928; Fisher 1939; Clark 1940), the authors are not yet aware of any empirical models to measure structural change in a value creation system. Literature often follows the innovation theory and tries to measure relationships between competition, market structures, firm characteristics and innovations (Aghion and Howitt 1990; Gilbert 2006; Cohen 2010). There are also research 
approaches to strategically positioning the companies in their market or value system (Blind et al. 2009; Appio et al. 2019) that however, do not take current change processes into account. Further empirical studies exist in business model research, where it is well established that decision-making at management level is influenced by change processes in the environment (Brown and Eisenhardt 1998). However, it is relatively silent on how impact mechanisms between change processes in the industry and business models can be characterised and how the resulting strategic decisions by companies unfold (Hacklin et al. 2018). Other studies investigate changes in market structures (Scherer and Ross 1990 (structure-conduct-performance-paradigm); Jaworski et al. 2000; Kjellberg et al. 2015). Malerba (2002) argues that in line with the system approach also change processes outside the value creation system, the groups of players and their interactions should take into account. Although, in management literature, there are comprehensive approaches that illustrate a company's environmental relations and thus, at least implicitly, the systemic influence of structural change on companies (Aldrich and Pfeffer 1976; Dyllick 1989; Rüegg-Stürm 2002), until now these have had little empirical orientation. There are also approaches that analyse the influence of megatrends on economic systems (Naisbitt 1982; Müller 2008; von Groddeck and Schwarz 2013; Ruff 2015). However, these studies analyse carefully selected changes without showing the interrelationship of their impact mechanisms. Against this background, the research aim of this paper is to investigate how change processes influence a value creation system and how affected groups of players react to them. As Hornsby et al. (2009) show, the attention of top management is of importance for the impact mechanisms of change processes and the strategic response. This is why decision-makers of real estate companies have been surveyed for this study.

The first objective of this paper is therefore to construct an explanatory model for the transformation of the real estate industry. Although its application is limited to the German commercial real estate sector, ${ }^{1}$ the purpose of this paper is to make a general contribution to the discussion of methodological measurement and evaluation of this transformation. The particular aim of the empirical study is to explore how drivers of structural change affect the business models of the various players in the German real estate industry and how they respond. Consequently, specific implications for the development of business models can be derived. Our investigation therefore pursues two research questions:

- How does the transformation exert adjustment pressure on the real estate industry and its players and how can it be measured?

- How are real estate industry players affected and how are they responding to the adjustment pressure?

\footnotetext{
${ }^{1}$ The subject of this paper is limited to the commercial real estate industry. In order to reduce complexity, housing industry aspects have to take a comparatively subordinate role.
} 
While research question 1 should rather confirm and evaluate relations derived from the literature, research question 2 pursues the aim of revealing correlations through an explorative procedure.

The paper is structured as follows. Section 2 provides a brief literature review of the investigation of change processes and corporate adjustments and derives the basic research model to explore research question 1. Section 3 describes the research design and the methodical approach to the empirical analysis. The results of the basic research model and hence the answers to research question 1 are presented in Sect. 4. Section 5 shows and discusses the results of how the players are affected and how they are responding to the adjustment pressure (research question 2). Finally, Sect. 6 concludes the paper.

\section{Literature background}

\subsection{Change processes and corporate adjustments}

In order to understand transformation, we first discuss literature on how change processes in the corporate environment have so far been investigated. Companies have to align their strategic decisions and management actions with their environment, which is subject to constant change (Mühlroth and Grottke 2018). These dynamics can provide new growth opportunities for companies (Veugelers et al. 2010) but can also pose a fundamental threat (von der Gracht et al. 2010). Innovation research also treats the external environment as an important determinant (Damanpour 1991), since the environmental dimensions act as changed demand and adjustment pressure factors, thereby generating important impetus for innovation (Miller and Friesen 1982; Sears and Baba 2011; Hügel et al. 2019). Perception and interpretation of the external environment is therefore of particular importance for the management, because it influences strategic decision-making (Tidd 2001; Alexiev et al. 2016; Hügel et al. 2019). The importance of change processes has actually increased, as a result of more complex and uncertain corporate environments. Companies have to adapt their business models, products and services, processes and corporate structures to these new conditions (Yoo et al. 2010; Buliga et al. 2016). The constant and fast-paced changes in the operating environment of the players in the real estate industry also mean that there will be continuing and increasing need to predict future demand for space and developments (Pfnür and Seger 2017).

The ways in which individual change processes affect the real estate industry and individual players are commonly part of real estate industry research. Several studies have examined the effects of urbanisation (Zhang 2001; Bart 2010; Deng et al. 2015), globalisation (Currit and Easterling 2009; Falkenbach and Toivonen 2010; Vongpraseuth and Choi 2015; Wijburg and Aalbers 2017) and demographic change (Brounen and Eichholtz 2004; Kroll and Haase 2010; Just 2013, 2017; Deschermeier and Voigtländer 2017). Toivonen and Viitanen (2016) have already noted that, although these studies provide valuable information about individual change processes, the lack of an overall context means that there is a paucity of research on the combined effects of the various change processes in the real estate industry. 
Other studies therefore use, for example, the environmental scanning (ES) research method, in order to forecast future change processes for particular markets or sectors. This method investigates the actions of various stakeholders, such as citizens, businesses, public authorities and other organisations, in order to identify and analyse the change processes affecting their environment. These change processes can include megatrends, trends, drivers or weak signals that relate to the socio-cultural, political, environmental and economic entirety (Gordon and Glenn 2009; Toivonen and Viitanen 2015). Megatrends are defined as long-term trends in relation to social, political, legal, sociocultural, technical and/or economic changes that cannot be influenced by individual players (Naisbitt 1982; Deckers and Heinemann 2008; von Groddeck and Schwarz 2013). Thus, they influence a broad spectrum and can amalgamate various individual trends (Vejlgaard 2008). Trends, on the other hand, have an impact in the medium to short term. However, there is a certain ambiguity in defining trends in terms of their duration or strength of action. Drivers of structural change are specific trends that not only occur but actually force a reaction: this does not apply to trends per se. Examples of the actual drivers of the megatrend digitalisation are technologies or changes in customer behaviour.

Another instrument reflecting influences from political, ecological, social and technological factors is PEST analysis, named after these factors (Rattanaprichavej 2014). This is a popular instrument for identifying macroeconomic factors. The analysis includes consideration of the external business environment. The basic principle of PEST analysis is that a company has to react to change processes in its external environment, because the company's strategy requires an accord between its own capabilities and the external environment (Gupta 2013). PEST analyses have been used to analyse the environment of a specific company as well as of an entire industry. However, PEST is far from being a precise and clearly defined analytical grid (Peng and Nunes 2007).

Research using these methods has provided a view of many different change processes and has helped the players in the real estate industry to understand how the drivers of change are manifested in their corporate environment (Toivonen and Viitanen 2016). However, these research projects are based on the premise that the players concerned adapt to the change processes in accordance with their own strategies and their own interpretation (Toivonen and Viitanen 2015). In this premise and awareness, Ansoff (1975) and Naisbitt (1982) see the possibility of anticipating the further consequences and of orienting actions towards a desirable outcome. Although it is relatively easyier to identify the major change processes, it is much more difficult to translate their exact meaning for a specific industry, the relevant markets, or even an individual company (Cook 2015). The aim of previous research has been to detect changes as early as possible, in order to assist decision makers in identifying possible threats and exploring opportunities (Mühlroth and Grottke 2018). However, these studies do not take into account the very diverse ways in which the change processes affect different players in an industry. In addition, it is of strategic importance for the players involved to understand not only the change processes that are happening but also how the overall mechanism of the transformation works. This requires a holistic understanding of the drivers of change, impact mechanisms and interactions. The reactions of the players in the value creation system 
must also be taken into account. Only then can strategic conclusions for the business model of the individual company be drawn. In this context, a basic research model was developed and subsequently statistically verified.

\subsection{Basic research model}

The concept that change processes can be attributed to the corporate environment, and therefore that companies are influenced by their environment, can be traced back to the system approach. This system approach is aimed at identifying previously unknown interconnections, as well as complex cause-effect relationships. It is therefore suitable for capturing complex processes in companies. As any company loses its raison d'être when it no longer complies with the requirements of its environment, companies rely on reacting to relevant influences in their environment. Ulrich (1970) had already elucidated that these environmental influences are not static but change over time, so that anticipating and adapting to circumstances in the outside world is an essential part of corporate behaviour. However, for a long period, fundamental change processes that are slowly starting to take place may be barely visible. With the help of the system approach, companies and their environment are characterised as dynamic systems with complex relationships and interdependencies (Rüegg-Stürm 2002). Picot (1981) describes a set of elements that have a relatively permanent relationship pattern with each other as a structure. It is precisely these long-term changes that lead to structural changes. These structural changes can be traced back to change processes that originate in a global environment of the value creation system (Diller and Lorch 1984; Schehl 1993). Fundamentally, the structural change must be differentiated from demand phenomena, market adjustments and short-term business changes, and in particular from the economic cycle (Streissler 1982; Diller and Lorch 1984; Müller-Stewens and Müller 2009). Structural change processes are, in principle, unique processes, while cyclical phenomena are recurrent (Helmstädter 1982). Indeed, the structural change in the growth process of capitalist economies can only be explained by the interaction of supply-side and demand-side factors (Hagemann 2011). Because of this close interdependence, particularly in business practice, structural changes cannot always be distinguished from commonplace market changes.

Empirical measurement and evaluation of structural change, in order to take account of the resulting pressure to make managerial decisions, is a particular challenge (Picot 1990). In order to establish a basic understanding of the effects of structural change on business management, the system approach is helpful, since a company is surrounded by environmental spheres and interaction issues (Rüegg-Stürm 2002). Within this frame of reference, three mechanisms that are responsible for structural change have been derived in order to set up the research model:

1. A change process is initiated by megatrends in the companies' global environment. The global environment includes all areas of economic and social life. As already outlined, megatrends affect widely differing areas of life, albeit in different forms. A preliminary exploratory study (see Sect. 3.1) showed that the 
German real estate industry is primarily influenced by the megatrends of globalisation, socio-demographic change, urbanisation, sustainability, digitalisation and changes in regulatory environment. These megatrends are very widespread as concepts, apart from changes in regulatory environment. This megatrend is intended to capture the fundamental changes in monetary and economic policy. Developments such as the low-interest phase, Brexit or even increasing trade tariffs, are increasingly motivated by nation states and foreign policy. In particular, we consider the longstanding political influence on the money supply and interest rates to be meaningful.

2. Megatrends may have an effect, but they are not relevant for action per se (von Groddeck and Schwarz 2013). Rather, this requires substantiation in the form of drivers of structural change. According to Picot (1981), these drivers can have differing relevance to decision-making by different players. The sum of the adjustment pressure of all the drivers then results in the structural change. The influence of the drivers of structural change on the value creation system of the real estate industry and individual groups of players is examined in more detail in the following. The value creation system comprises all players in the real estate industry, which can be subdivided into four main groups according to their business models: (1) occupiers of commercial real estate, (2) real estate investors, (3) operational service providers and (4) property developers. ${ }^{2}$

3. The adjustment pressure on companies undergoing structural change comes, however, not only from outside but also from inside the value creation system. If a company adapts to the adjustment pressure caused by the drivers of structural change, for example by changing its business model or its products and processes, this adaptation process can itself have effects on the interaction environment and may even become a driver of structural change for other companies. The structural change is propagated inside a value creation system by reciprocal strategic-tactical interactions between the players. In this way, even megatrends and drivers of structural change that actually have no direct relationship to a business model or a specific company may gain relevance to decision making indirectly, via the adaptation strategies of other players in the interaction environment of a company.

These three impact mechanisms accelerate the transformation, which leads to fundamental changes in the real estate value creation system. The first aim of this paper is to answer research question 1 and therefore to determine whether these impact mechanisms have an effect in the form presented above, and how they can be measured. Therefore, the following three impact mechanisms must first be tested as a basic research model:

\footnotetext{
2 This subdivision is based on Pfnür (2011), who divided the players in the real estate industry into the three main groups (1) occupiers of commercial real estate, (2) real estate investors, (3) developers, producers and service providers, based on their perspectives of real estate management and their objectives. In the study, the third group of players was subdivided into two, in order to take into account the special characteristics of property developers in comparison with service providers.
} 
M1 Megatrends cause indirect adjustment pressure due to changes in the global corporate environment

M2 Drivers of structural change lead to direct adjustment pressure and thus to corporate adjustments

M3 Interactions between the players in the value creation system increase the adjustment pressure and thus the necessity for corporate adjustments

These mechanisms are tested using structural equation models. The resulting research model is presented at the end of the next section (Fig. 2), once the research design and methodology have been explained.

\section{Research design and methodology}

\subsection{Exploratory preliminary study}

The empirical study was preceded by an exploratory preliminary study, since explorative research is appropriate to enable statements to be made about a problem that is not, or only little, known (Mayer 2009; Busch et al. 2013). The aim was to gain an understanding of the far-reaching processes of transformation, the impact mechanisms of megatrends, drivers of structural change and adaptation strategies of the players in the real estate industry. Hardly any academic research has so far been undertaken on the transformation of the real estate industry. Practice-oriented management literature provides approaches as to which change processes are relevant but does not make use of systematic or scientific methodology (e.g. Oertel et al. 2014; Bölting et al. 2016; Staub et al. 2016; Weber 2017; Schmidiger et al. 2017; Vornholz 2017). Therefore, the preliminary study consisted of an analysis of practice-relevant management literature and 25 exploratory expert interviews, conducted with selected decision-makers and opinion leaders, using a semi-structured questionnaire. In order to generate knowledge, personal interviews in the form of key question interviews are suitable (Mayer 2009; Gläser and Laudel 2010). The selection of experts to be interviewed reflected the particular viewpoints of the four main groups of players: i.e. occupiers of commercial real estate, real estate investors, operational service providers and property developers.

The different terms (identified megatrends, drivers of structural change and adaptation strategies) were discussed and coded until a consensus had been reached by the interviews, enabling the subsequent empirical survey to illustrate the overall complexity with as few items as possible. During the process of adapting the terms and items, we referred back to the experts consulted and made appropriate changes to the wording, in order to avoid making changes that would impair content validity, as suggested by Rhee et al. (2012).

The first result was that the experts interviewed agreed on the mechanisms of transformation. In addition, 6 megatrends and 16 drivers of structural change that are relevant to the German real estate industry were identified. The megatrends have already been mentioned in the previous section. Together with the drivers of structural change, they are presented in Table 1 in Sect. 4 (listed as indicators for the 
adjustment pressure). The relevant adaptation strategies, dependent on the group of players identified in this way, are shown in the figures in Sect. 5.

\subsection{Sample selection and data}

The decision-makers in the German real estate industry approached were those...

1. ...whose decision-making powers are important for structural change in the real estate industry. The companies in the real estate industry were assigned to groups of players and sorted by size. In each of the largest companies, potential survey participants were identified, based on the description of their functions, from those concerned with strategic tasks in the company and/or entrusted with the further development of the business model, products and services.

2. ... who, as opinion leaders, have special influence on the change processes in the real estate industry. The relevant interviewees were identified on the basis of authorship of pertinent management-oriented articles in specialist journals and at conferences and workshops.

Overall, care was taken to ensure that the aggregate of the participants in the individual strata corresponded to their significance for the entire real estate value creation system. The gross sample included 1,344 decision-makers in the German real estate industry (Fig. 1).

Within the acquired sample, 42 commercial real estate occupiers, ${ }^{3} 62$ operational service providers, 111 real estate investors and 34 developers took part in the empirical section of the study, which therefore surveyed 249 decision-makers from the top management of the German real estate industry. The net sample equated to a response rate of $26.55 \%$ (Pfnür and Wagner 2018). ${ }^{4}$ The survey was conducted by computer-aided telephone interviews, on the basis of a structured questionnaire. The respondents answered predominantly closed questions, using a six-point Likert scale, with $1=$ strongly agree and $6=$ strongly disagree. The answers "Don't know" and "I prefer not to answer" were also allowed.

Five blocks of the questionnaire are relevant for the purposes of this evaluation. First, the respondents were asked about the influence of megatrends on the real estate industry. In the second block, they were asked about the necessity for corporate adjustments. These questions were divided into four items: necessity to adapt the companies own business model; products and services; corporate structure; or processes. The third block consisted of querying essential influences on the

\footnotetext{
${ }^{3}$ Corporate Real Estate Managers in a narrower sense were surveyed. Therefore, not all commercial real estate occupiers such as retailers and general office occupiers such as lawyers or tax consultants are included in the survey. When survey participants were asked about the influence of occupiers on their own work, real estate occupiers in a broader sense was meant, as no delimitation was made in the questionnaire.

4 Adjusted for decision-makers no longer active in the company and participants who could not be reached despite at least 3 (on average 5.8) contact attempts, the net sample was 938.
} 


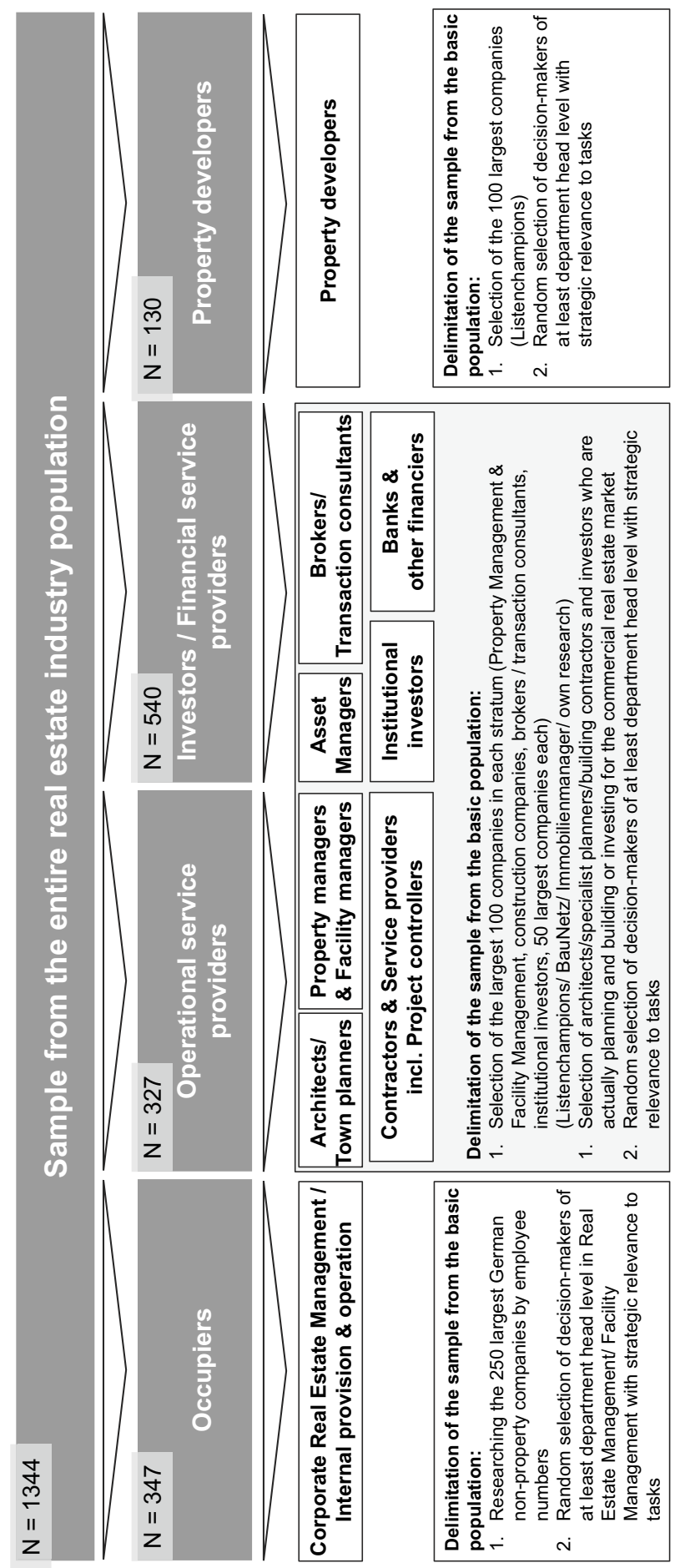

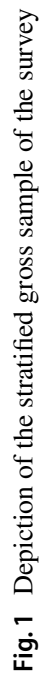


real estate industry, thus questioning the significance of the 16 drivers of structural change. In the fourth block, questions were asked about the corporate changes taking place among the players in the real estate industry. These indicators reflect the reaction to the current change processes and thus the adjustment strategies. This questionnaire block differed between the four groups of players. Finally, the decision-makers were asked to provide their assessment of the influence of the adaptation strategies of other players on their own companies.

The sample can be deemed representative of the population as a whole. The larger proportion of investors mirrors the actual situation in the industry: $37 \%$ of the companies in the real estate industry are active in all aspects of real estate trading, letting, brokerage and management, and are responsible for two-thirds of the turnover in the industry (Just et al. 2017b). There are slightly fewer operational service providers, due to the predominantly small units in this sector of the industry. Furthermore, because of the two selection criteria, it can be assumed that professionally active decision-makers in the real estate industry were over-represented. Although this cannot be shown statistically, a slight bias towards professionality should be taken into account in the results.

In order to avoid common-method bias, the measures recommended by Podsakoff et al. (2003) were considered. The participants were assured that the evaluation would be anonymous. They were further informed that there were no correct or incorrect answers and that they should answer as honestly as possible (Podsakoff et al. 2003). A single-method-factor approaches test (Harman's-one-factor-test) shows no methodological bias for all structural equation models. As with Vance et al. (2012), as an additional test, all latent variables were examined for a correlation of 0.9 or higher. No correlations as high as this were found. It is therefore considered unlikely that this study is subject to a common methods bias. In order to rule out a non-response bias as far as possible, all participants in the gross sample were contacted several (on average 5.8) times by telephone, as well as by personal letters by post and e-mail. A non-response bias was also tested, using the method recommended by Armstrong and Overton (1977). No significant differences were found between the first third and the last third of respondents' data, so that such biases can also be regarded as unlikely. ${ }^{5}$

\subsection{Structural equation modelling}

In order to answer the research questions empirically, the variant-based approach of structural equation modelling and hence partial least squares structural equation

\footnotetext{
${ }^{5}$ In order to rule out a non-response bias, the following additional aspects are crucial: (1) For all participants and items, the two answers "Don't know" and "I prefer not to answer" occur in less than $0.8 \%$ of responses. Furthermore, we did not detect any statistical anomalies with regard to this response behaviour. (2) We kept attention high through the personal telephone interviews, we did not ask for any personally sensitive information in the survey and guaranteed absolute anonymity. (3) By querying the function and position of respondents, we ensured that decision-makers who actually fit the criteria had been interviewed. Although a non-response bias cannot be completely ruled out, we argue that the potential for bias would be greater if participants were forced to make assessments that they did not believe themselves capable of.
} 


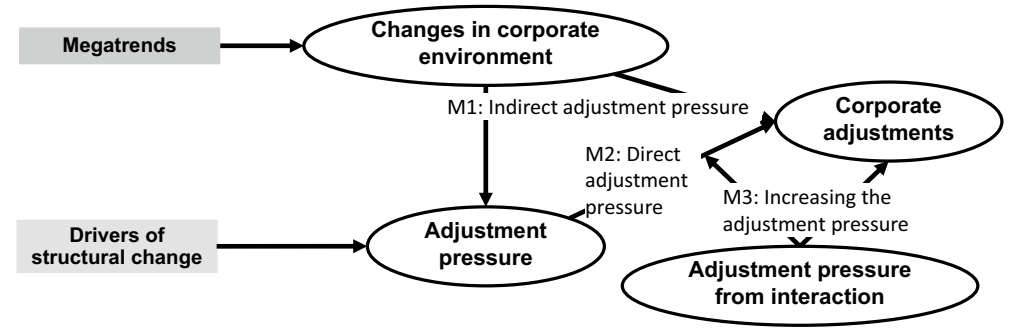

Fig. 2 Modelled path diagram for empirical testing of the three impact mechanisms (research question 1)

modelling (PLS-SEM) has been applied (Homburg et al. 2008; Hair et al. 2017). This is especially appropriate for handling smaller sample sizes (Chin and Newsted 1999; Henseler and Sarstedt 2013). PLS-SEM has advantages for exploratory research (Henseler et al. 2014) and is suited for mediation analysis (Preacher and Hayes 2008).

All calculations were carried out using the software SmartPLS, Version 3. With regard to settings, the recommendations of Wong (2013) and Hair et al. (2017) are followed. There are no missing values from the data set: the telephone interviews ensured that all questions were answered and no questionnaire was prematurely terminated. However, the possible answers "Don't know" and "I prefer not to answer" resulted in missing values, which were dealt with in accordance with the recommendations of Hair et al. (2017). Observations with more than $15 \%$ missing values were excluded. Other missing values, which occurred in less than $5 \%$ of the instances of the items surveyed, were replaced by the mean. ${ }^{6}$ This resulted in a sample of 249 respondents for the calculations for empirical verification of the basic research model (Sect. 4). The sample sizes for the structural equation models of each of the subgroups (Sect. 5) are different and are shown in the figures of the presentation of results.

The structural equation model used to measure the impact mechanisms of the transformation in order to answer research question 1 is shown in Fig. 2. Since the six megatrends trigger the changes in the corporate environment according to the established theory, these are measured using a formative measurement model. The same applies to the 16 drivers of structural change, with regard to the adjustment pressure. The adjustment pressure through interaction is measured with the aid of the changes anticipated by the decision-makers interviewed, through the adaptation strategies of the other players. The measurement model is formatively constructed, since the influence of the changes on the players concerned reinforces the adjustment pressure. Formative measurement models should technically cover the essential facets of a construct (Hair et al. 2017). This purpose was served by the exploratory preliminary study, which included literature research and qualitative interviews (Diamantopoulos and Winklhofer 2001; Jarvis et al.

\footnotetext{
6 The results do not differ substantially from the other methods: the quality criteria for mean substitution are even somewhat more robust.
} 
2003; Hair et al. 2017). Since the items could not be taken from previous scientific studies but only from management-oriented literature and explorative interviews, the expert interviews were also used as preliminary tests, to avoid major issues with content validity and reliability. The corporate adjustments are measured reflectively, with the aid of four indicators.

For empirical testing of impact mechanism 1 and thus the indirect effect of megatrends on company adjustments, a mediation was modelled. The influence of adjustment pressure on corporate adjustments (mechanism 2) is tested as a direct effect. Since the theory assumes that the adjustment pressure from interaction strengthens the fundamental influence of the adjustment pressure on the corporate adjustments, a moderator variable was modelled here, to test mechanism 3 . When testing these mechanisms, no distinction was made between the groups of players, since the impact mechanisms on the entire value creation system are to be shown.

The results of an exploratory factor analysis are used to examine research question 2 through the structural equation models. The factor analysis reduces the complexity of the drivers of structural change and the adaptation strategies and shows, which drivers act as a bundle and which adaptation strategies the respective players actually pursue. The factors formed in this way form the latent variables in the real estate players-related structural equation models. The approach is based on the idea that drivers of structural change can be condensed into content-related contexts of impact (BBSR 2019). The respective internal structural equation models investigate the influence of the driver groups identified on the major adaptation strategies determined using the exploratory factor analysis. The structural equation models that were developed differ between the players. Both the groups of drivers and the adaptation strategies were measured as latent variables, by means of reflective measurement models. Figure 3 shows an example. The individually calculated structural equation models are shown in Sect. 5. The corresponding adaptation strategies have been named by the authors depending on the items loaded on them.

Finally, the validation of all measurement models takes place at this point. As the constructs have to be reliable. Cronbach's alpha (CA), composite reliability (CR) and the average variance extracted (AVE), which should exceed 0.7, 0.7 (Bagozzi and Yi 2012) and 0.5 (Hair et al. 2013), were analysed for the reflective

Fig. 3 Exemplary representation of the investigation of the influence of the drivers of structural change on the adaptation strategies of the individual groups of players (research question 2)

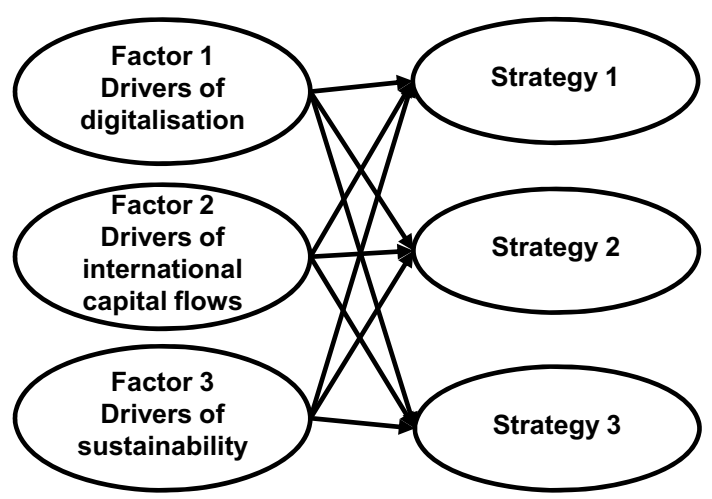


measurement models. Whereas CA values between 0.6 and 0.7 are regarded as acceptable in exploratory studies (Hair et al. 2017), these values are recognized as not being strict cut-offs (Bagozzi and Yi 2012). The discriminant validity is assessed by the Fornell-Larcker criterion. Additionally, cross-loadings, which have to be lower than the loadings on their respective constructs (Henseler et al. 2015) were checked. For investors, the construct drivers of international capital flows barely achieve the desired CA value (0.561). For property developers, the Fornell-Larcker criterion shows that strategy 2 and strategy 5 do not differ significantly. For operational service providers, only the average variance extracted for the drivers of digitalisation, 0.474, did not exceed the general guideline. Since, apart from these very few exceptions, all the standard quality criteria of the structural equation models have been fulfilled, for an explorative study well-compiled models can be assumed. As all pairs of variables display VIF values well below the threshold of 5 (Hair et al. 2013), it can be concluded that multicollinearity should not be an issue. With regard to the f-square values, it can be said that all statistically significant influences of the internal structural equation models are also considerable and meaningful.

Although researchers should be very cautious to report model fit in PLS-SEM (Hair et al. 2017), it can be noted that the value of 0.08 for standardized root mean square residual (SRMR) in the basic research model can be considered to be a good fit (Henseler et al. 2014).

\section{Results and discussion of the empirical testing of the basic research model}

Figure 4 shows the path diagram with the associated results of the impact mechanisms, using a structural equation model. Table 1 shows all corresponding items sorted by their constructs. The means and standard deviations of their univariate evaluation, together with the loadings and significance levels in the structural equation model, are also shown.

In order to test the indirect influence of megatrends and hence mechanism M1, we ran a mediation analysis (Preacher and Hayes 2008). As a first result,

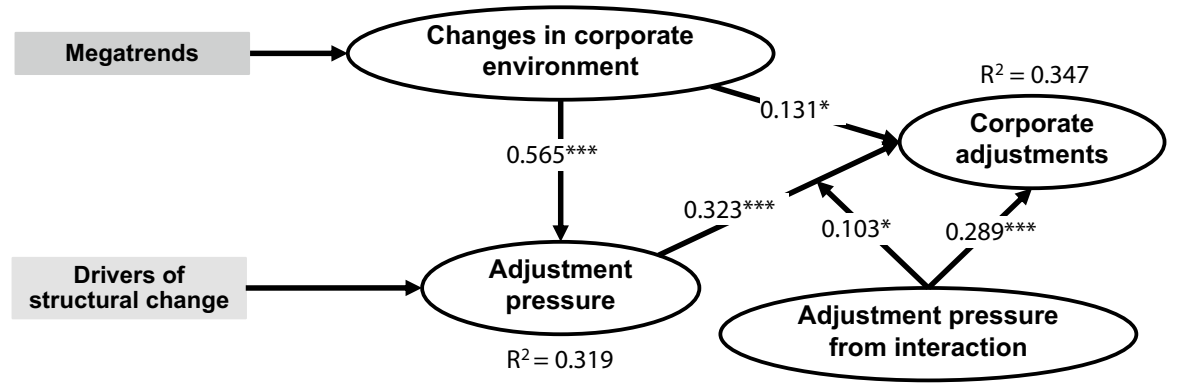

Fig. 4 Results of calculating of the basic research model (research question 1). Notes: $n=249$. ${ }^{*} \mathrm{p}<0.1$, $* * \mathrm{p}<0.05, * * * \mathrm{p}<0.01$ 
the changes in the corporate environment triggered by megatrends have a much stronger effect on the adjustment pressure $(\beta=0.565, \mathrm{p}<0.01)$, than on corporate adjustments $(\beta=0.131, \mathrm{p}<0.1)$. The changes in the corporate environment also show an indirect effect on corporate adjustments $(\beta=0.182)$. This indirect effect is statistically significant, because the confidence interval [2.5\%: $0.118 ; 97.5 \%$ : 0.302] does not include the value of zero (Hair et al. 2017). Since both the indirect and the direct effects are statistically significant and have the same sign, there is a complementary mediation.

Following mechanism M2, the results show that the adjustment pressure caused by drivers of structural change leads to corporate adjustments $(\beta=0.323$, $\mathrm{p}<0.01)$. Consequent to mechanism M3, an adjustment pressure through the effect of adaptation strategies of other players arises from the interaction $(\beta=0.289, \mathrm{p}<0.01)$. The modelled moderation effect is evident $(\beta=0.103$, $\mathrm{p}<0.1)$. The influence from the interaction therefore has an effect both on the corporate adjustments per se and a reinforcing effect on the influence of the adjustment pressure on the corporate adjustments. Table 1 shows the indicators, descriptive results and indicator loadings.

The transformation of the real estate industry is currently being most strongly countered by the players at the level of process and product optimisation. The empirical results in Table 1 show that changes in structures and business models are less important. In contrast to the automotive industry, for example, where the major vehicle manufacturers are developing into mobility service providers, the opportunities offered by digitalisation are being used only haltingly to develop new business models in the real estate industry.

As a result, three impact mechanisms have been identified as ways the transformation puts adjustment pressure on the construction and real estate industry and their players and how these can be measured. As impact mechanism M1 states, megatrends have only an indirect influence on the players. The mean values in Table 1 show that digitalisation is only one megatrend among many. In particular, urbanisation and socio-demographic change are of greater importance for the German real estate industry. However, the main influence on corporate adjustments comes from the drivers of structural change. Megatrends are therefore less important as drivers of structural change for the corporate adjustments. The model has an abstract approach but, in contrast to environmental scanning (ES) or PEST and STEEP, specific interdependencies can be shown and measured. This is a foundation set for further research. In order to show the extent to which the various players in the real estate industry are affected by the adjustment pressure and, in particular, to examine the adaptation strategies that are pursued as a result (research question 2), we will therefore focus on impact mechanism M2. Although the third impact mechanism is also of major relevance to research and practice, it did not form part of the further investigation. 


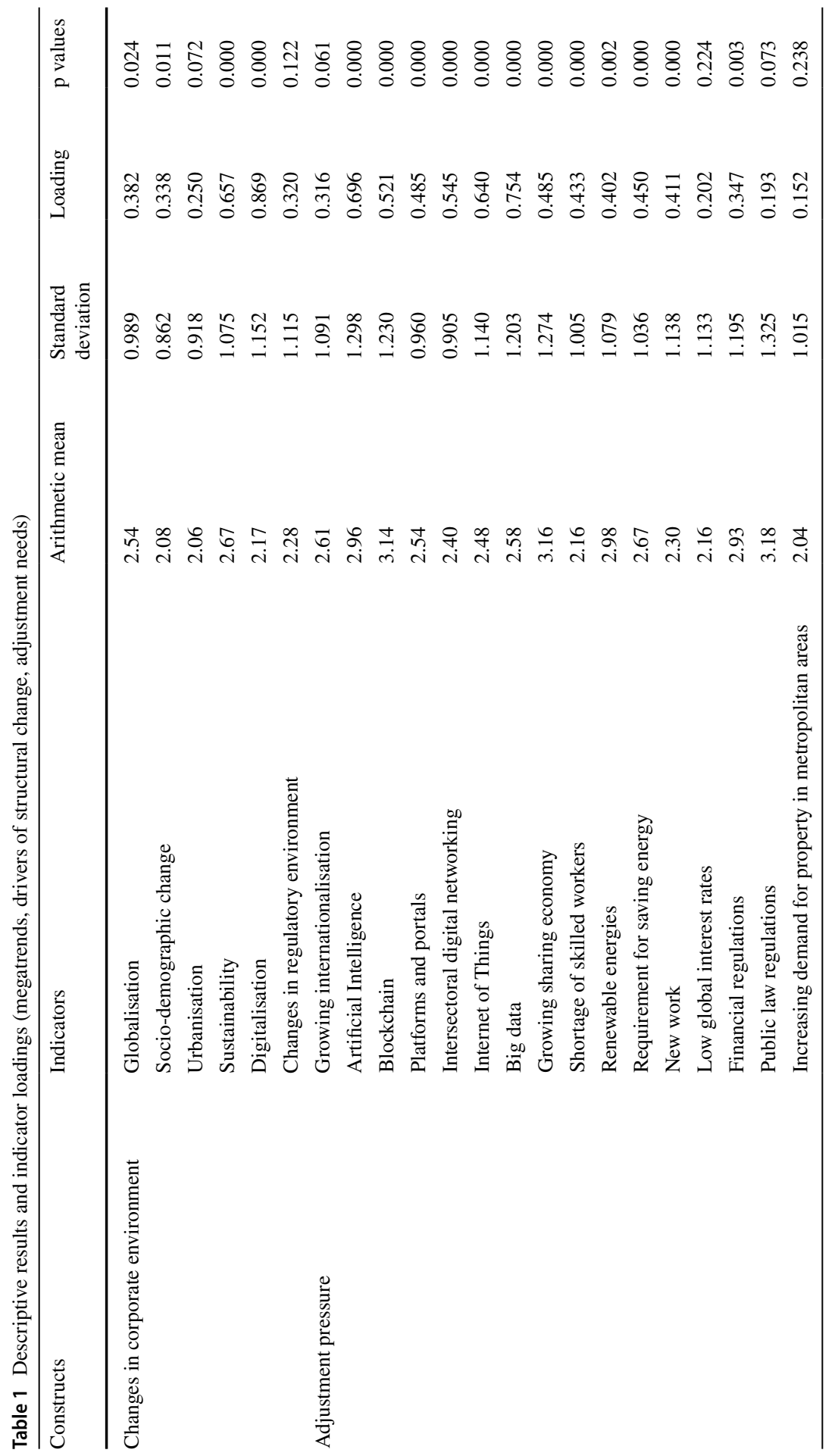




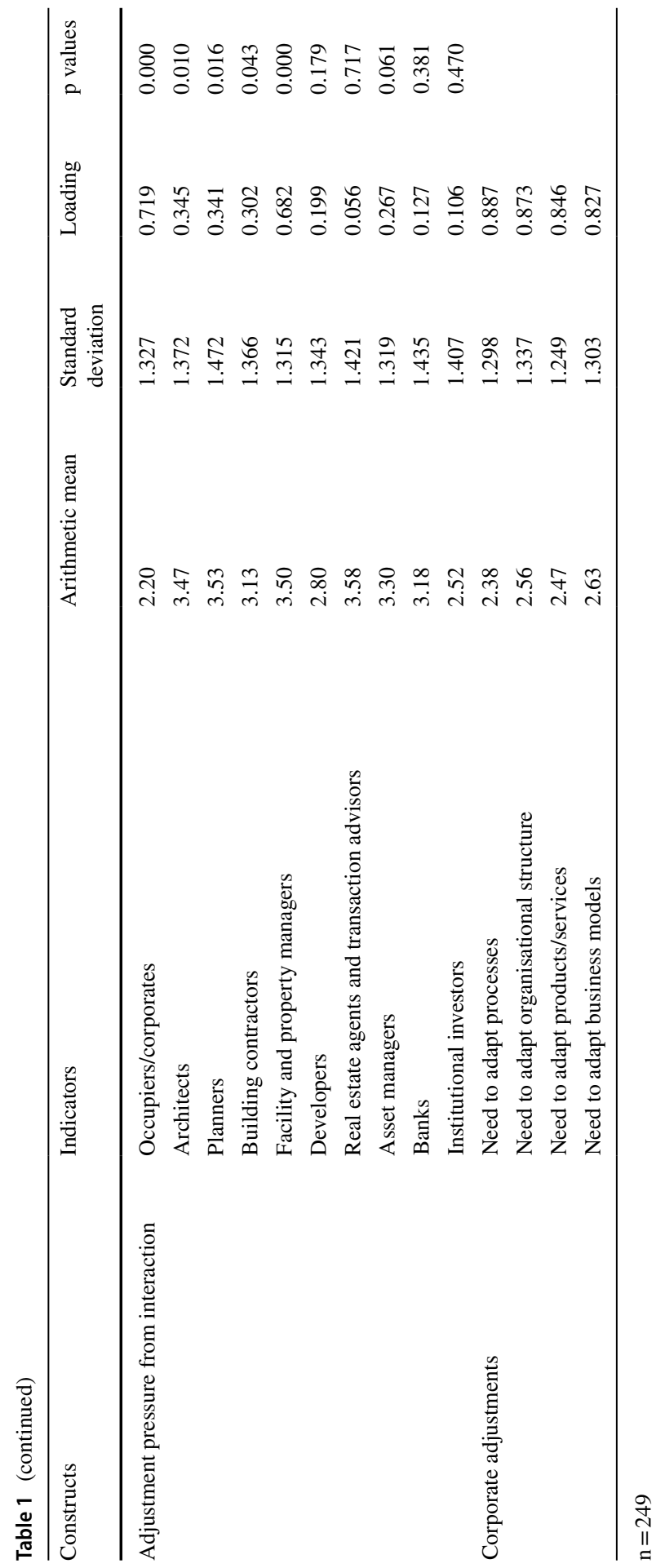




\section{Results and discussion of the relationship between the drivers of structural change and the adaptation strategies of the groups of players}

In order to understand the transformation process in the real estate industry, it is necessary to create a comprehensive picture of how and with which adaptation strategies, each group of players reacts to the drivers of structural change. The results are first presented according to the four groups of players and then discussed in Sect. 5.5.

\subsection{Occupiers of commercial real estate}

From the explorative factor analyses, three groups of drivers of structural change and five essential adaptation strategies result for occupiers of commercial real estate. Figure 5 shows the resulting structural equation model to investigate the influence of the drivers of structural change on the adaptation strategies.

The mean values, loadings and quality criteria of the individual items in the reflected measurement models are shown in Table 6 in the Appendix. The correlation and path coefficients for the correlation and influence of the drivers of structural change on the individual adaptation strategies by occupiers are shown in Table 2.

The strongest adjustment pressure for the occupiers of commercial real estate results from the drivers of digitalisation. They influence innovative provision of space, flexibility, optimisation of space efficiency and innovative services. These results demonstrate the vital importance of digitalisation for the real estate industry. Digitalisation is changing the quantitative and qualitative demand for space in business and society. The univariate analyses of the mean values (Table 6 in the Appendix) also clearly show that there is a very high level of uncertainty about future space requirements. Occupiers react to this with flexibility as the most important adaptation strategy shown by the mean value analysis.

The second most important adaptation strategy is the optimisation of space efficiency. The cost pressure on space of German companies thus remains high. The digitalisation drivers can act as enablers here. Of third highest importance is adaptation strategy 5, innovative services. This is where the digitalisation drivers exert their strongest influence. Demand for integrated solutions and asset services is increasing. The first experiences of the strategy of innovative provision of space, which is also important, are evident in the changed requirements for new and digital working environments, such as non-territorial workplaces and co-working.

The drivers of international capital flows influence the strategy of concentration in metropolitan regions. In real estate financing, they are concentrated on inner-city locations. However, the mean value comparison shows that this strategy is hardly relevant. This means that, according to the corporates surveyed, demand for space in city centre locations will not increase. Finally, the drivers of sustainability have no major effect on the adaptation strategies of the occupiers of commercial real estate. The additional single item construct New Work exerts an influence on strategy 5 of innovative services $\left(\beta_{45}=0.295, \mathrm{p}<0.05\right)$. Conversely, the shortage of skilled workers has no influence on the occupiers' adaptation strategies. 


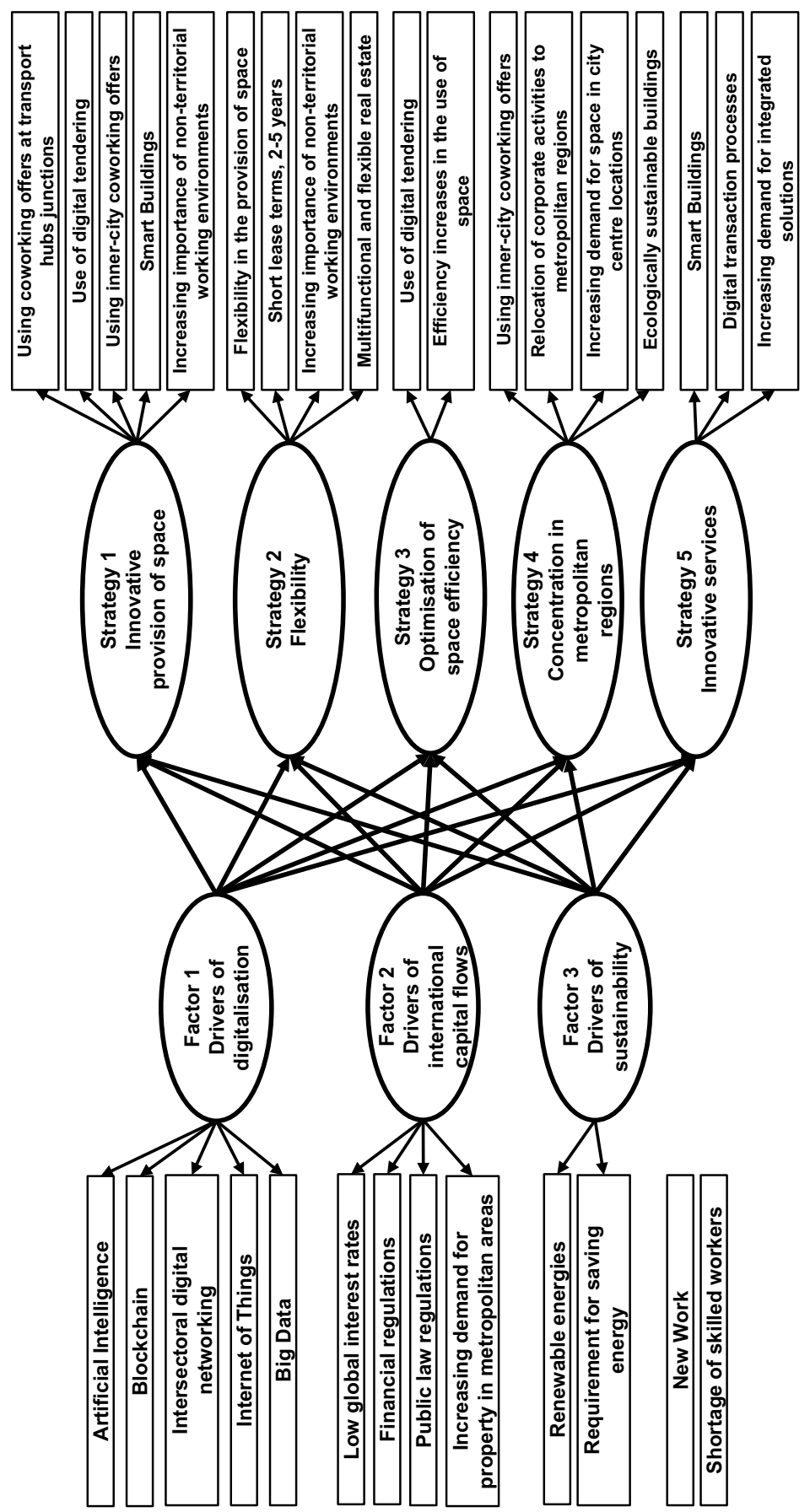

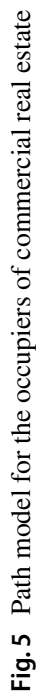




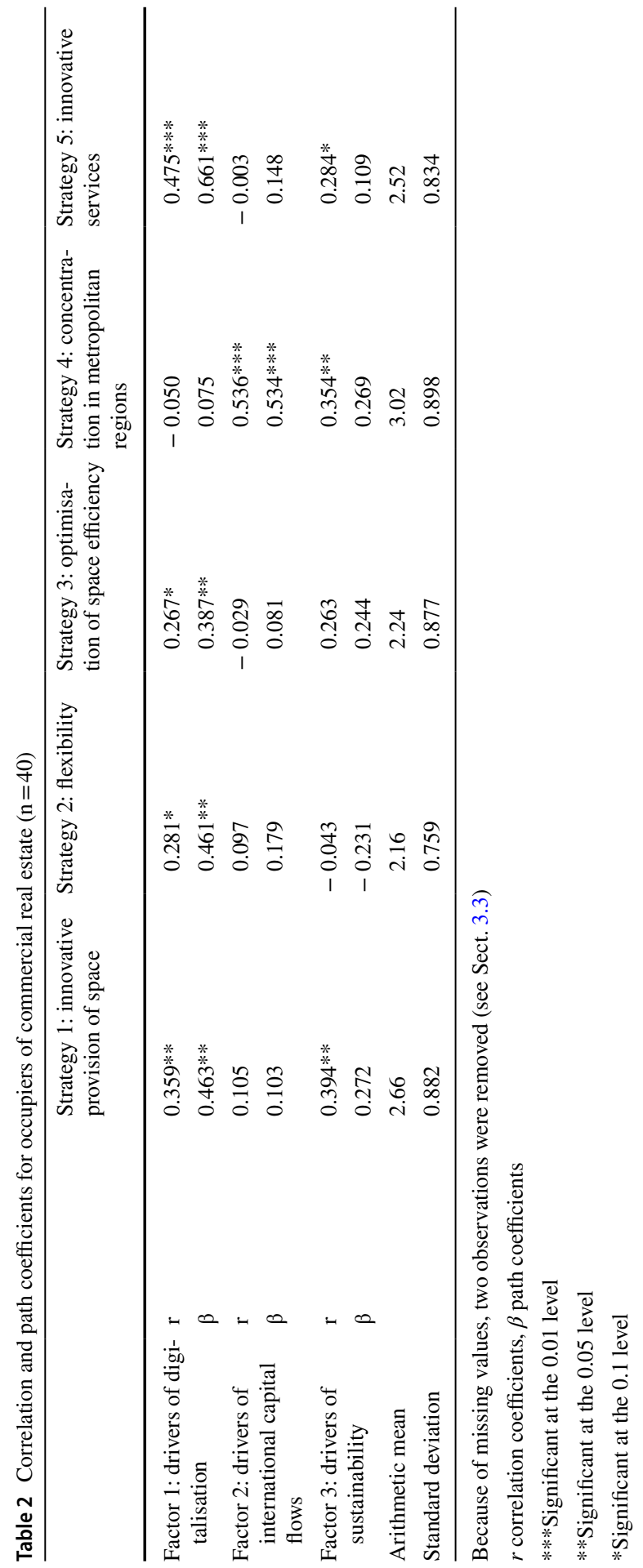




\subsection{Property developers}

The factor analyses revealed four driver groups ${ }^{7}$ and six adaptation strategies for the property developers. The corresponding structural equation model formulated for the developers is shown in Fig. 6.

Again, the mean values, loadings and quality criteria of the respective items in the reflected measurement models are shown in Table 7 in the Appendix. The correlation and path coefficients for the correlation and influence of the drivers of structural change on each of the adaptation strategies for property developers are shown in Table 3.

The developers are the group of players for whom the results of the correlation analysis and those of the structural equation model are most clearly differentiated. The comparatively small sample size is a possible reason. However, the statistical quality criteria are fully adequate for an exploratory study and the results are not self-contradictory. Below, we focus on the outcomes of the structural equation model, since this has the higher statistical explanatory power.

Overall, property developers are exposed to the strongest influence from the drivers of structural change. The mean values show that the developers are pursuing their adaptation strategies very intensively. They are the most active group of players in the transformation.

The digitalisation drivers require new and innovative products and thus development activities by the property developers, which are also probably driven by a changed demand. This is demonstrated by the influence of the drivers of digitalisation on the strategy of developing new asset classes. The influence of the drivers of digitalisation on the digitalisation of property development is highly statistically significant. The most significant influence, however, is on adaptation strategy 4 , i.e. increasing the breadth of value added. The influence of drivers of digitalisation means that developers are perceiving the growing importance of integrated real estate services and integrated operator models. This is changing the orientation of their business models. Within the framework of the statistical evaluation, the question as to whether the drivers of digitalisation are actually driving or are merely enabling these adaptations among property developers remains unanswered.

In contrast, the influence of the drivers of international capital flows on the property developers is somewhat weak, sometimes even negligible. The only correlation is between them and adaptation strategy 3, new asset classes. The search for international capital flows for existing and for new forms of investment is directly linked to the development of new asset classes. However, it does not actually trigger any appreciable influence.

On the other hand, the developers are most widely influenced by the drivers of sustainability, which are leading them towards strategies that cope with the new requirements for buildings, or even assuming an operator function and therefore

\footnotetext{
7 For the developers, a distinction must therefore be made between the drivers of international capital flows and the political drivers. On the other hand, in the approach to developers, the digitalisation drivers' platforms and portals, sharing economy and cross-industry digital networking have been disregarded, as they do not weight the corresponding factor.
} 


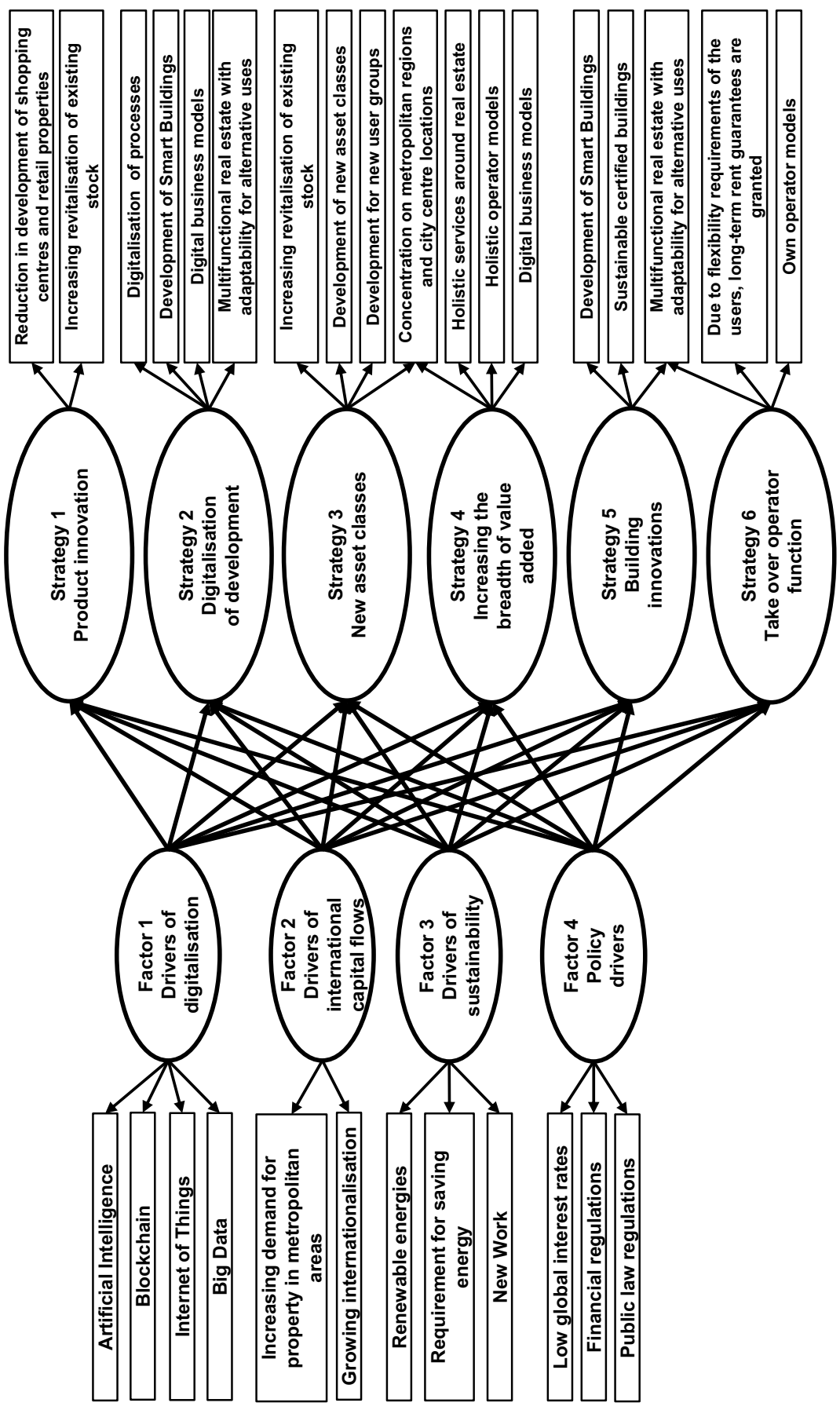

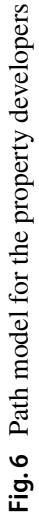




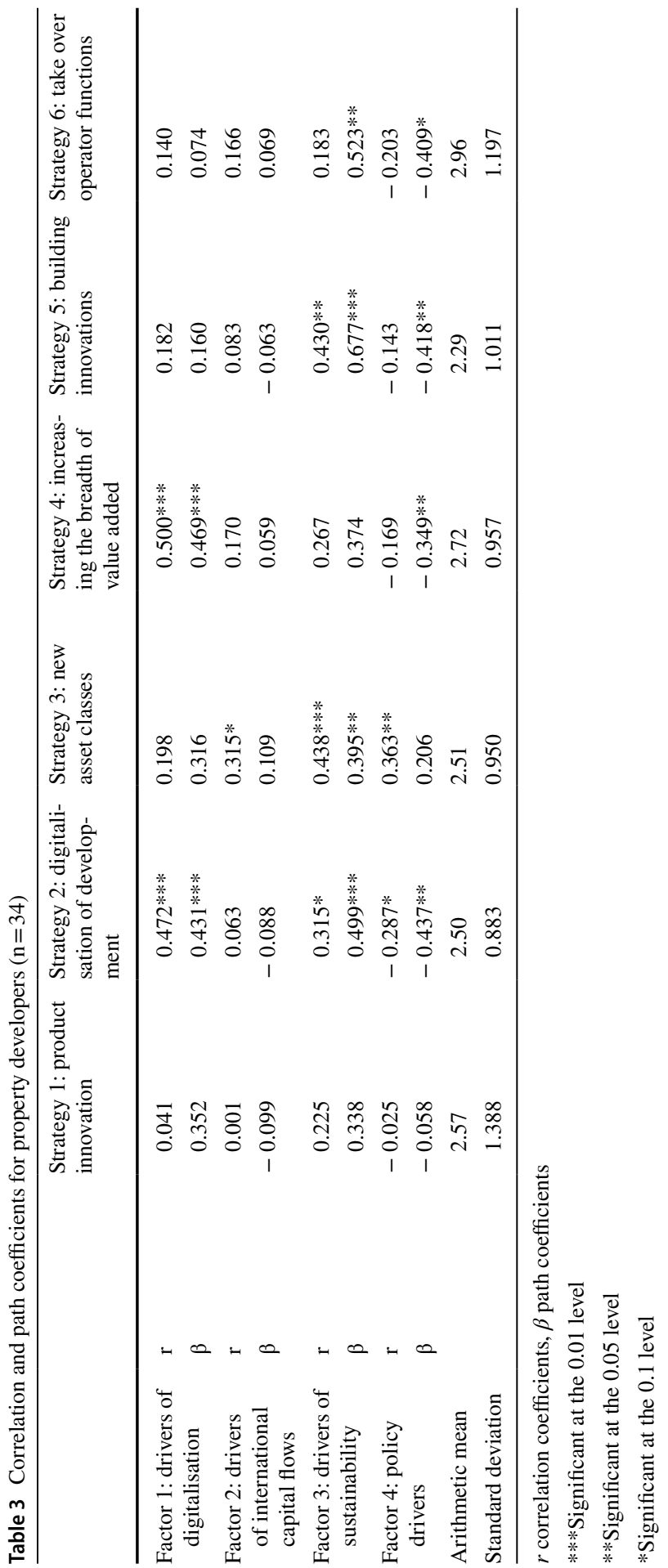


taking over a further phase in the real estate life cycle. The additive effect of the change drivers is also evident here, since the survey participants awarded the drivers of sustainability little significance in themselves. This influence is also strongly affected by social sustainability in new working environments. New Work leads to new requirements for space, which makes building innovations necessary. These new requirements of occupiers also influence the strategy of taking over operator functions. In this context, the current trend towards flexible office space, which also affects project developers strategically, could be of relevance.

For the developers, the policy drivers have a specific negative influence on the relevant adaptation strategies, above and beyond the three previous drivers of structural change. The policy drivers are more likely to be interpreted as hurdles to the corresponding adaptation strategies by the property developers.

\subsection{Investors}

The exploratory factor analysis results in three driver groups ${ }^{8}$ and four major adaptation strategies for investors. Figure 7 shows the path diagram for the analysis of the investors' subgroup. Mean values, loadings and quality criteria are shown in Table 8 in the appendix.

The path coefficients determined using the structural equation model largely confirm the results of the correlation analysis between the drivers of structural change and the real estate investors' adaptation strategies (Table 4).

For investors, the structural change in the real estate industry primarily means pursuing occupier-oriented investment strategies. This is due to the drivers of digitalisation, the drivers of international capital flows and the drivers of sustainability having an influence on Strategy 1. However, the mean value analysis shows that this is not the most intensive adaptation strategy for the broad range of investors.

The digitalisation drivers lead to the potential for outsourcing partnerships in real estate management. With these partnerships, the control of real estate management can be made more efficient. This is particularly likely to apply to large fund managers, who may often be remote from specific properties and tenant groups. However, the average value of 3.09 indicates that this strategy has not yet been rigorously pursued. So far, therefore, recognition of the potential of the drivers of digitalisation is limited to the ability to supervise real estate management in a success-oriented manner.

The drivers of digitalisation have the strongest influence on digital business models and products. However, the average value of 3.12 shows that investors consider Strategy 4 to be the least considerable adaptation strategy. Although their strong influence shows that the drivers of digitalisation are already highly relevant for action, investors are still acting very cautiously in this respect. This indicates that German investors have yet to identify the potential of the drivers of digitalisation, or

\footnotetext{
${ }^{8}$ For the subgroup of real estate investors, the structural change drivers of increased demand for space in conurbations and public-law regulations do not load the factor driving international capital flows. When considered individually, public-law regulations are of little significance for the investors surveyed.
} 


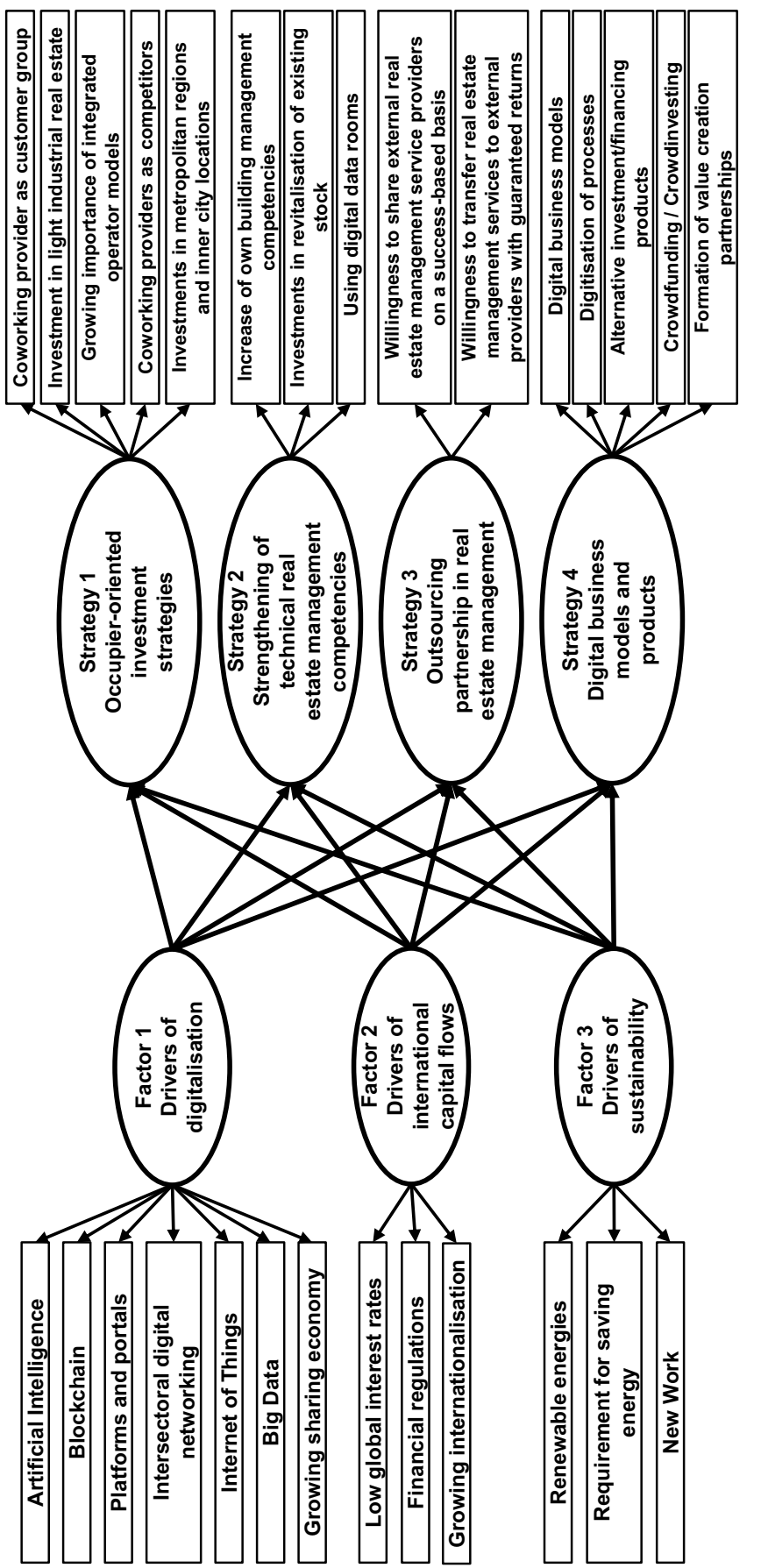

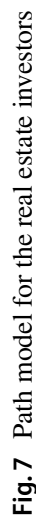




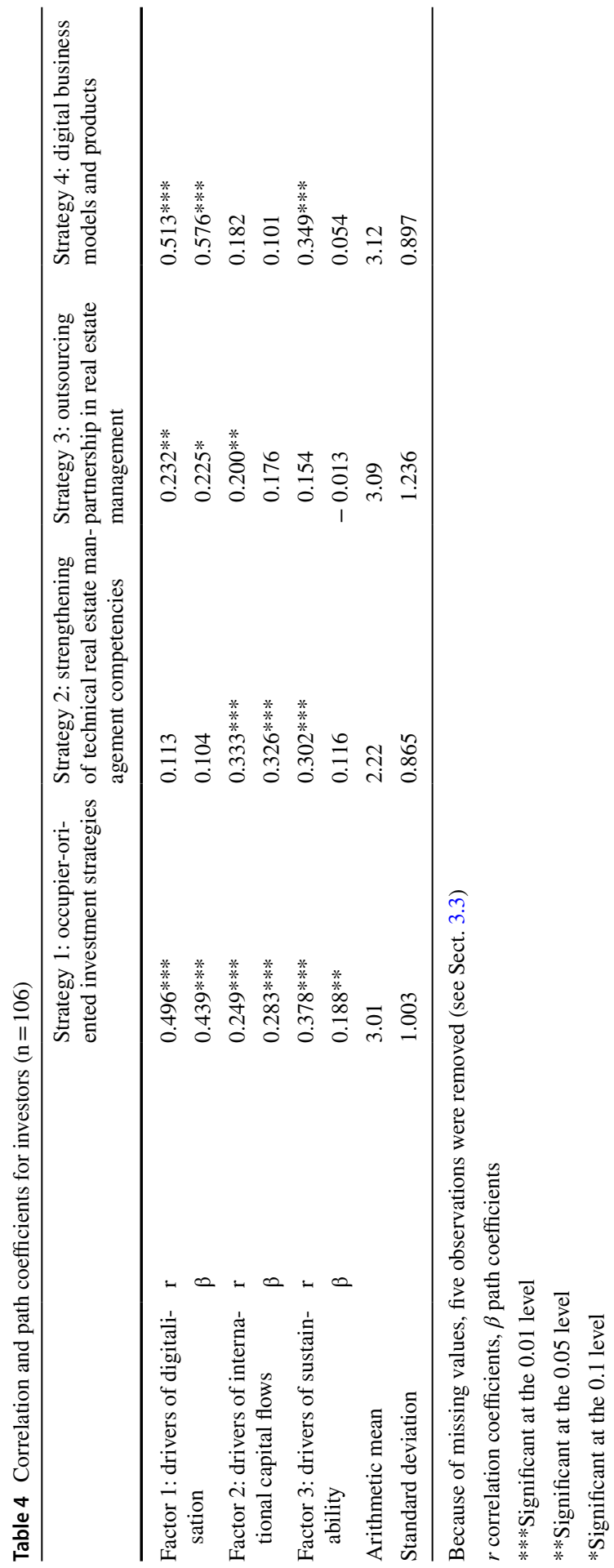


perhaps that, in the current healthy economic situation, there has been no need for far-reaching adjustments.

The influence of international capital flows on the strengthening of technical real estate management skills is also an occupier-orientation by investors. As an adaptation strategy, the investors are increasing their building management skills, thereby collaborating more closely with the occupiers of the properties. With an average value of 2.22, this strategy is of greatest importance to investors. Investors are expanding their business models to include such additional services.

\subsection{Operational service providers}

The exploratory factor analysis reveals that this group of players is responding to the transformation process with four essential adaptation strategies. The resulting structural equation model is shown in Fig. 8. ${ }^{9}$

The mean values, loadings and quality criteria of the individual items in the reflective measurement models are shown in Table 9 in the appendix. Table 5 shows the results of the correlation analysis and path coefficients between the drivers of structural change and the adaptation strategies.

The results indicate strong correlations and influences of the drivers of digitalisation on the operational service providers' adaptation strategies. The influence on the strategy of business area expansion shows the potential provided by digitalisation, in combination with corresponding technologies. However, the average value of 3.38 indicates that the majority of service providers have not yet taken advantage of this potential. The influence on product and service innovations is also high, although the average value of 2.79 shows that this strategy is also not in the focus of service providers. This demonstrates that, fundamentally, the drivers of digitalisation can enable innovative service products and system solutions, based on the model of "as a service" concepts. However, instead of optimising the business model, digitalisation is currently enabling service providers to increase the efficiency of existing activities. The digitalisation of service provision, with an average value of 2.16 , is therefore the most important adaptation strategy in structural change, despite this not being influenced by the drivers of structural change.

The clear influence of drivers of sustainability on the use of digital technologies indicates that performance-based service providers are using them to meet sustainability requirements in the construction and, in particular, the operation of real estate.

For the operational service providers interviewed, by means of a supplementary single-item construct, the shortage of skilled workers is exerting a negative influence on the innovation of products and services $\left(\beta_{44}=-0.206, \mathrm{p}<0.05\right)$. This shortage is therefore the primary factor standing in the way of the provision of all new forms of services by the operational service providers.

\footnotetext{
${ }^{9}$ For the operational service provider group of players, the driver of structural change of growing internationalisation of the markets does not load the factor of the driver of international capital flows.
} 


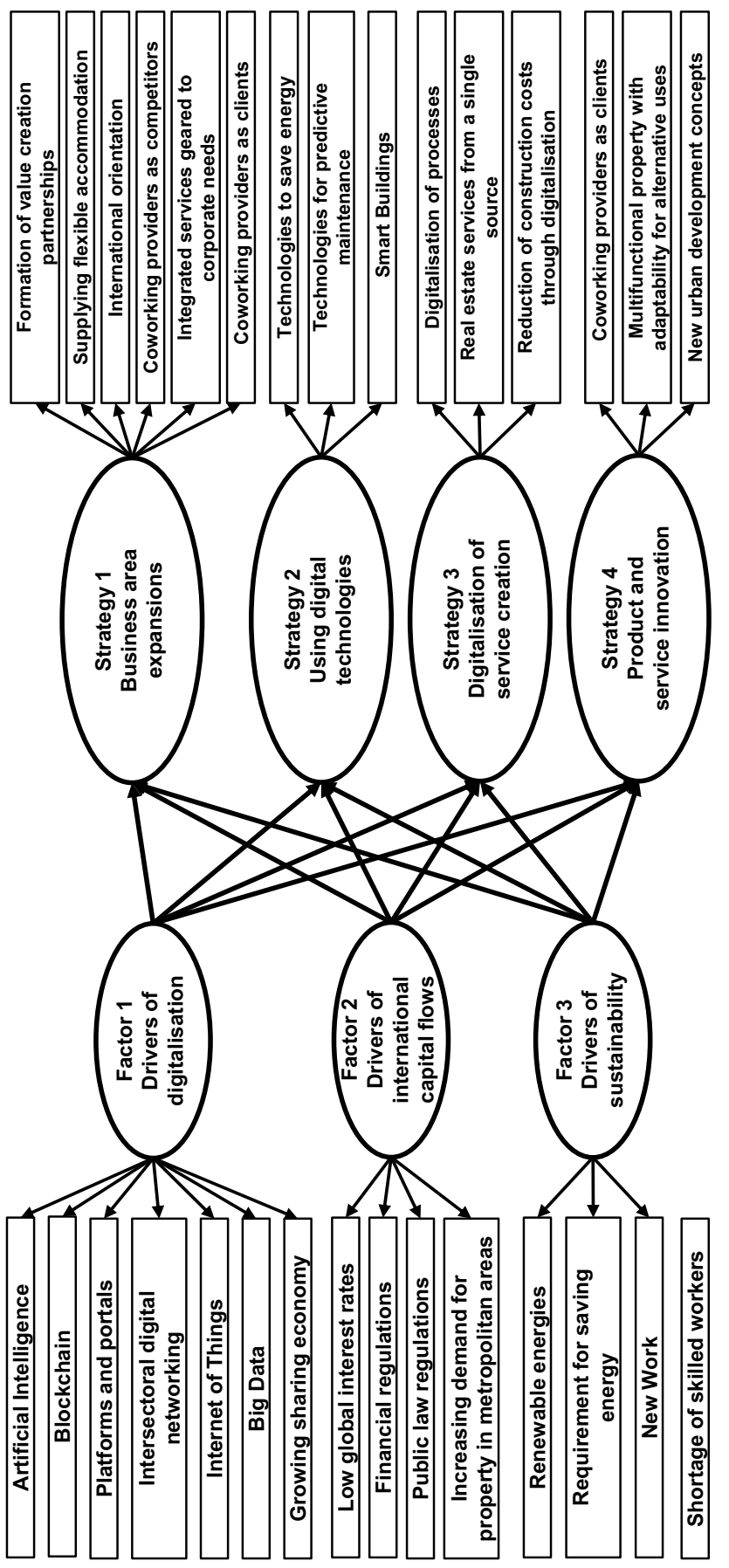

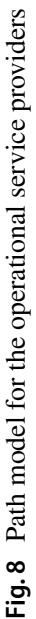


Table 5 Correlation and path coefficients for the operational service providers $(n=61)$

\begin{tabular}{|c|c|c|c|c|c|}
\hline & & $\begin{array}{l}\text { Strategy 1: business } \\
\text { area expansions }\end{array}$ & $\begin{array}{l}\text { Strategy } 2 \text { : using } \\
\text { digital technologies }\end{array}$ & $\begin{array}{l}\text { Strategy } 3 \text { : digi- } \\
\text { talisation of service } \\
\text { creation }\end{array}$ & $\begin{array}{l}\text { Strategy } 4 \text { : prod- } \\
\text { uct and service } \\
\text { innovation }\end{array}$ \\
\hline \multirow{2}{*}{$\begin{array}{l}\text { Factor 1: drivers } \\
\text { of digitalisa- } \\
\text { tion }\end{array}$} & $\mathrm{r}$ & $0.517 * * *$ & $0.309 * *$ & 0.205 & $0.366 * * *$ \\
\hline & $\beta$ & $0.554 * * *$ & $0.235^{* *}$ & 0.135 & $0.376 * * *$ \\
\hline \multirow{2}{*}{$\begin{array}{l}\text { Factor } 2 \text { : drivers } \\
\text { of interna- } \\
\text { tional capital } \\
\text { flows }\end{array}$} & $\mathrm{r}$ & 0.002 & -0.091 & 0.031 & $0.245^{*}$ \\
\hline & $\beta$ & 0.062 & -0.209 & -0.120 & 0.253 \\
\hline \multirow{2}{*}{$\begin{array}{l}\text { Factor 3: drivers } \\
\text { of sustain- } \\
\text { ability }\end{array}$} & $\mathrm{r}$ & -0.029 & $0.406 * * *$ & 0.143 & $0.245^{*}$ \\
\hline & $\beta$ & -0.196 & $0.350 * *$ & 0.317 & 0.036 \\
\hline \multicolumn{2}{|l|}{ Arithmetic mean } & 3.38 & 2.62 & 2.16 & 2.79 \\
\hline \multicolumn{2}{|l|}{ Standard deviation } & 0.992 & 1.066 & 0.847 & 1.069 \\
\hline
\end{tabular}

Because of missing values, one observation was removed (see Sect. 3.3)

$R$ correlation coefficients, $\beta$ path coefficients

$* * *$ Significant at the 0.01 level

**Significant at the 0.05 level

*Significant at the 0.1 level

\subsection{Implications of the empirical results for the real estate value system}

A closer look at the interaction of the survey results from the individual groups of players shows that the transformation of the real estate industry originates from the occupiers. The drivers of digitalisation in particular, as well as the new working environments, are pressuring them to provide space that is both more innovative and more efficient. They are therefore increasingly focusing on holistic solutions. Just et al. 2017a, Pfnür and Seger 2017 and Pfnür 2019 have shown that the occupiers of commercial real estate lack sufficient capacity to implement these strategies themselves. This leads to the conclusion that corporates will have to rely on service providers to solve their problems. This could, for example, consist of offers of complete solutions, or value-added partnerships (Meyer 2016), as are already being seen in sectors such as IT outsourcing.

Property developers are responding to the changed demand from occupiers of commercial real estate with new development activities and stronger occupier orientation (see strategies 3, 5 and 6). The influence of the drivers of structural change on increasing the breadth of value added is evident, even if the policy drivers represent an obstacle. Although not all property developers are yet following the same broad trend, this is a reaction to changing occupiers' needs rather than the influence of capital market flows. For property developers, the potential for increased customer benefit in the transformation is directed more toward the occupiers of commercial real estate than to investors.

Investors will strengthen their in-house real estate management skills, primarily in order to better understand the use concepts of the properties and to be able to better follow the changed occupiers' requirements (see strategies 1 and 2). However, elsewhere the study results show that the already strong inflow of foreign capital into 
the German real estate markets is continually increasing (Pfnür and Wagner 2018). In the future, this will require a balance between strategies that are geared more strongly to changing occupiers' needs and those serving the international interests of the capital markets. This is because the international investors may not yet have realised the shifts in demand in the German letting markets and are therefore continuing to seek office space in the centres of the metropolitan regions. The results for investors show that, although the driving forces behind digitalisation have been identified, corresponding adaptation strategies seem (still) to be of weak relevance for action, especially against the background of the current strong economic phase.

The adaptation strategies of the operational service providers are influenced by the drivers of structural change. However, the mean values show that the adaptation strategies that are exposed to the strongest influence are attributed the least importance. In the transformation so far, the operational service providers appear to have focused on increasing the efficiency of traditional processes and fields of activity. This is instead of using the drivers of digitalisation with their digital technologies as enablers for expanding their fields of activity or product and service innovations, although the connections and influences show that the digitalisation drivers, in particular, offer a broad spectrum of opportunities in the real estate industry. The primary reason for this is insufficient capacities and resources for problem-solving competence, identified as the lack of qualified staff. The shortage of skilled workers remains one of the greatest challenges facing the construction industry (Deutsche Bauindustrie 2018).

All results interpreted in the overall context show that the real estate industry is not positioned as a holistic, integrated value creation system and is continuing to suffer from enormous inefficiencies in this respect. In particular, the operational service providers are still acting from the perspective of a classic supply industry, accustomed to reacting to tenders rather than working proactively. There is a lack of holistic solutions for the provision of space tailored to the relevant occupiers.

Property developers are recognising, at least in part, the gap in the market for real estate services. In their adaptation strategies, they are considering extending their value chains towards offering the complete solutions demanded by occupiers (see strategies 4 and 6). The property developers, however, are still predominantly medium-sized companies whose problem-solving capacities are limited in relation to the major investment needs of commercial real estate occupiers. This shows that the industry is not yet properly prepared for this massive change in space, capital and real estate services. In particular, the only slowly proceeding occupier orientation, coupled with the healthy economic situation of construction and real estate companies and the acute shortage of skilled workers, are currently preventing the transformation of the real estate industry. The results show that there are both opportunities and risks and so a pressure to act, that has not yet been sufficiently identified by the individual real estate players.

\section{Conclusion, further research needs and limitations}

This paper demonstrates the relevant change processes for the German real estate industry. It provides a methodological approach for understanding and empirically measuring the transformation of the German real estate industry. The results show 
that the megatrends from the global environment, which are much discussed in and beyond the real estate industry, only have an indirect influence on the individual players in the value creation system. The drivers of structural change currently exhibit the most substantial effect, creating adjustment pressure on the real estate players. The paper therefore demonstrates that, when considering change processes in a value creation system, the specific drivers of structural change are more important than the much-discussed megatrends. The results also show that the adjustment pressure is intensified by interaction with other players in the value creation system.

The research paper elucidates the situation in which the four main groups of players in the real estate industry are affected and the adaptation strategies they are currently using to respond to the adjustment pressure. Looking at these results of research question 2, a holistic picture of the transformation of the German real estate industry emerges. Commercial real estate occupiers are the driving force behind the transformation. The massive changes in space requirements and, above all, in the way space is provided, mean that occupiers, at least the large corporates, are looking for holistic and flexible solutions to counter the growing uncertainties in their requirements for space. In their development activities, property developers are reacting to this with a stronger orientation towards occupiers. Investors are also recognising the potential of focusing on occupiers' requirements, even if this is not (yet) highly relevant to action in the strategies they are currently pursuing. Service providers are responding by increasing the efficiency of their existing processes and activities, rather than by strategically realigning their business models. The lack of qualified staff in particular appears to be a major reason for this.

The issue is whether the adaptation strategies pursued by the groups of players in the real estate industry will be adequate to satisfy the occupiers' changing requirements. Financing and development are less of a bottleneck than the operational services of planning, construction and, in particular, operation. The healthy economic situation that has continued for years, together with the historic organisation of the construction process as a pure appropriation industry, are apparently proving to be an obstacle to the transformation of real estate industry business models. Nevertheless, there is considerable potential for digital business models, particularly in the more flexible use of resources and the creation of holistic solutions (Sampere 2016; Moring et al. 2018). During the last years co-working providers, who were originally far removed from the industry, have demonstrated how business models offering digital and integrated solutions could also find their way into the real estate industry. The traditional players surveyed here have yet adequately to recognise this potential. The players in the real estate industry clearly have not yet satisfied the changes in occupiers' requirements. If the real estate industry does not provide appropriate solutions for the commercial real estate occupiers' space requirements, this disinclination to change would pose a potential threat to the transformation of the German economy as a whole and consequently to its overall international competitiveness.

The need for further research can be derived from this. A closer investigation of the interactions in the real estate industry and the change processes of its individual players, based on this research, is therefore necessary. In addition, analysis of the transformation within individual companies would certainly be of further 
interest. For example, using the methods of Action Research, the effects of structural change in a company could be monitored over time.

The limitations of this research relate primarily to the collection of data at a specific point in time. In the currently dynamic economic situation of the real estate industry, decision-makers are less able — and less inclined - to discern the need for changes and adjustments. At the same time, more recent issues, such as on climate policy, are not reflected in the data. In addition, the possibility that business cycle effects might play a role in the perception of the managers surveyed cannot be completely excluded, notwithstanding the very sensitive formulation of the questions. As with most surveys, we cannot completely rule out selection biases, even though we have taken measures to reduce them as much as possible. Furthermore, although the total sample of 249 participants from top management can be regarded as large, the sample sizes for some of the subgroup analyses, such as property developers, are quite small. There is a strong generalisation of real estate companies and their business models, as these have been classified into groups of players for methodological reasons. For even more detailed findings, further studies should therefore differentiate between the various groups of players. Other limitations were that mainly large, and fewer medium-sized companies, were surveyed and the public sector was excluded from the study. In particular, only those occupiers of commercial real estate who have CREM formed part of the sample. A further limitation might be that one participant in the preliminary study also took part in the survey. Furthermore, the study does not consider all drivers of structural change but rather concentrates on those identified as most relevant in the preliminary study. As a result, digital technologies as drivers are considered in great detail, while political and economic drivers may be underrepresented. Nevertheless, the study provides important insights for understanding the transformation of the real estate industry and offers a sound basis for further research.

Acknowledgements The authors thank the editors Prof. Dr. Wolfgang Breuer and Prof. Dr. Bertram Steiniger for their encouragement in the constructive and appreciative review process. We would also like to thank the two anonymous referees for their detailed reviews with helpful comments and suggestions for improvements. The authors also acknowledge the open access funding provided by Projekt DEAL.

Open Access This article is licensed under a Creative Commons Attribution 4.0 International License, which permits use, sharing, adaptation, distribution and reproduction in any medium or format, as long as you give appropriate credit to the original author(s) and the source, provide a link to the Creative Commons licence, and indicate if changes were made. The images or other third party material in this article are included in the article's Creative Commons licence, unless indicated otherwise in a credit line to the material. If material is not included in the article's Creative Commons licence and your intended use is not permitted by statutory regulation or exceeds the permitted use, you will need to obtain permission directly from the copyright holder. To view a copy of this licence, visit http://creativecommons.org/licen ses/by/4.0/.

\section{Appendix}

See Tables 6, 7, 8 and 9. 


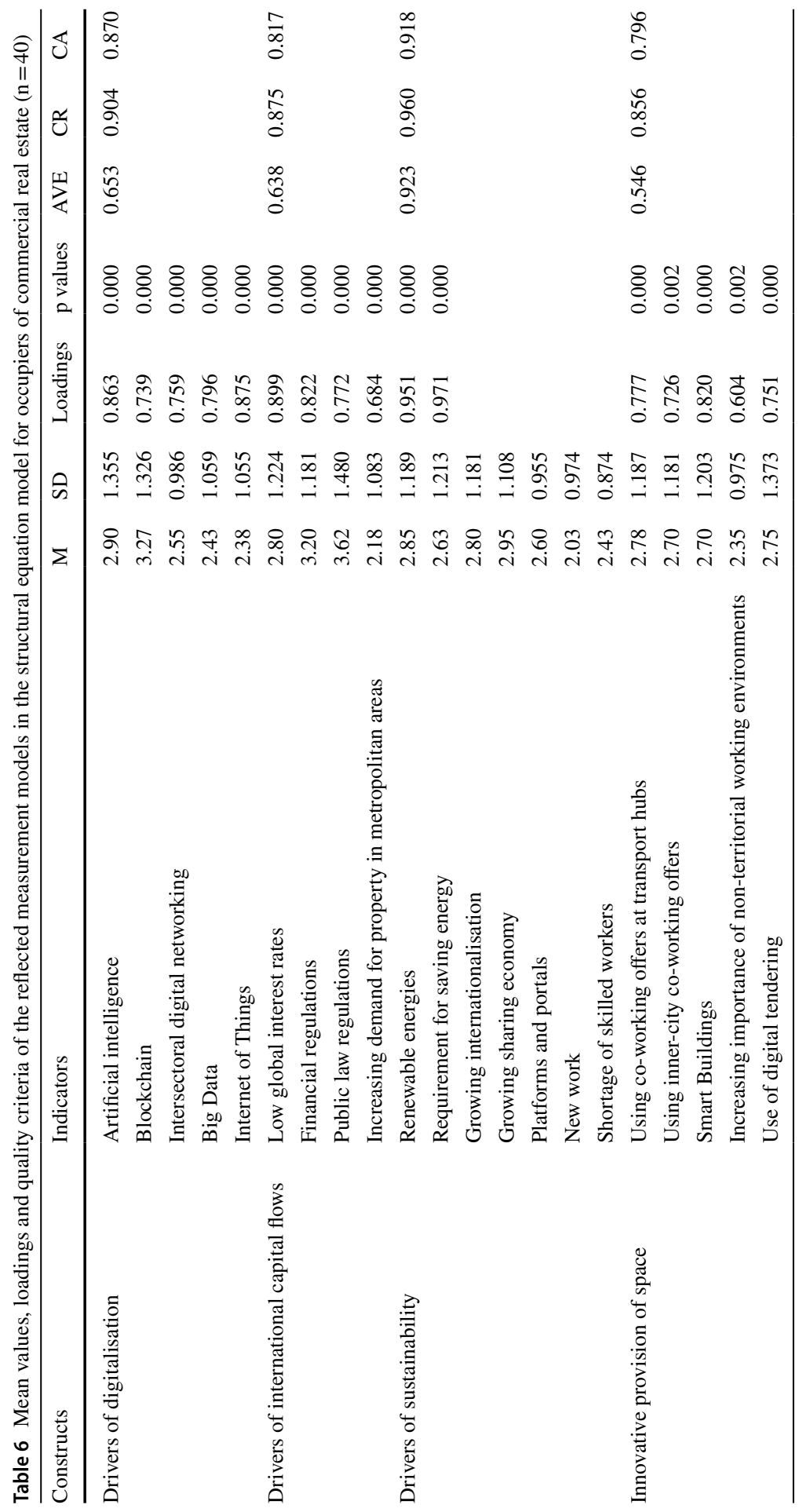




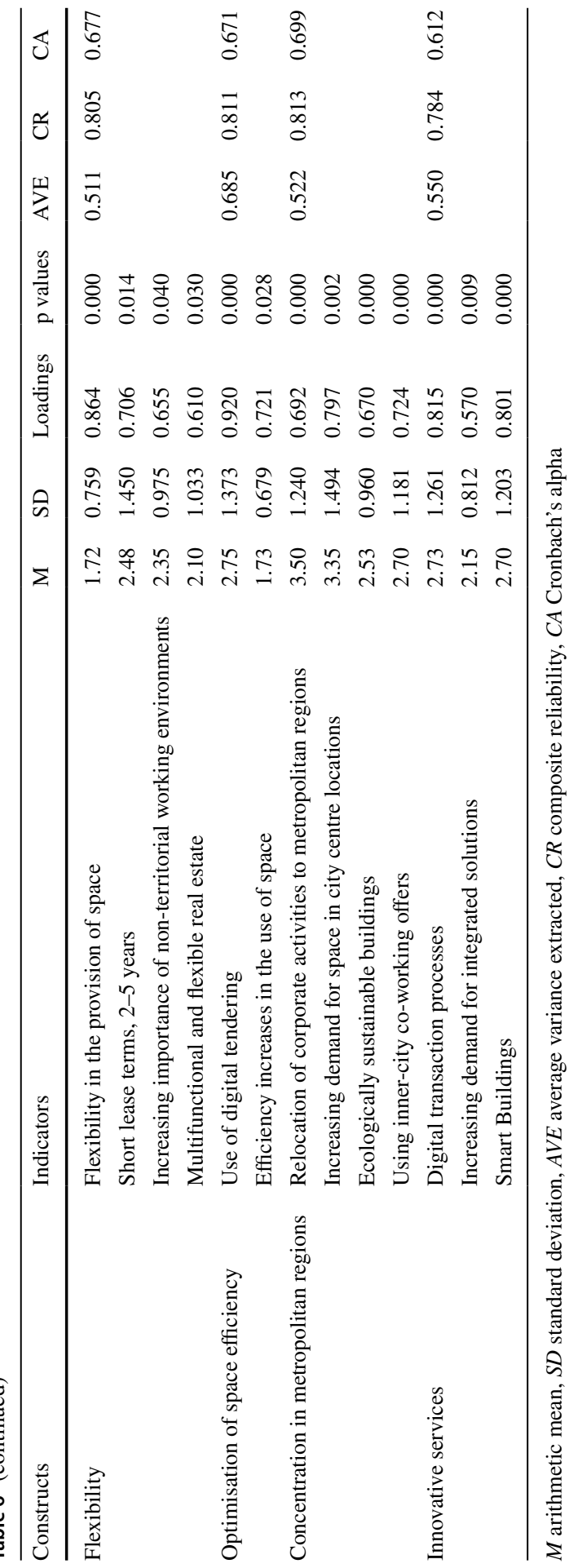




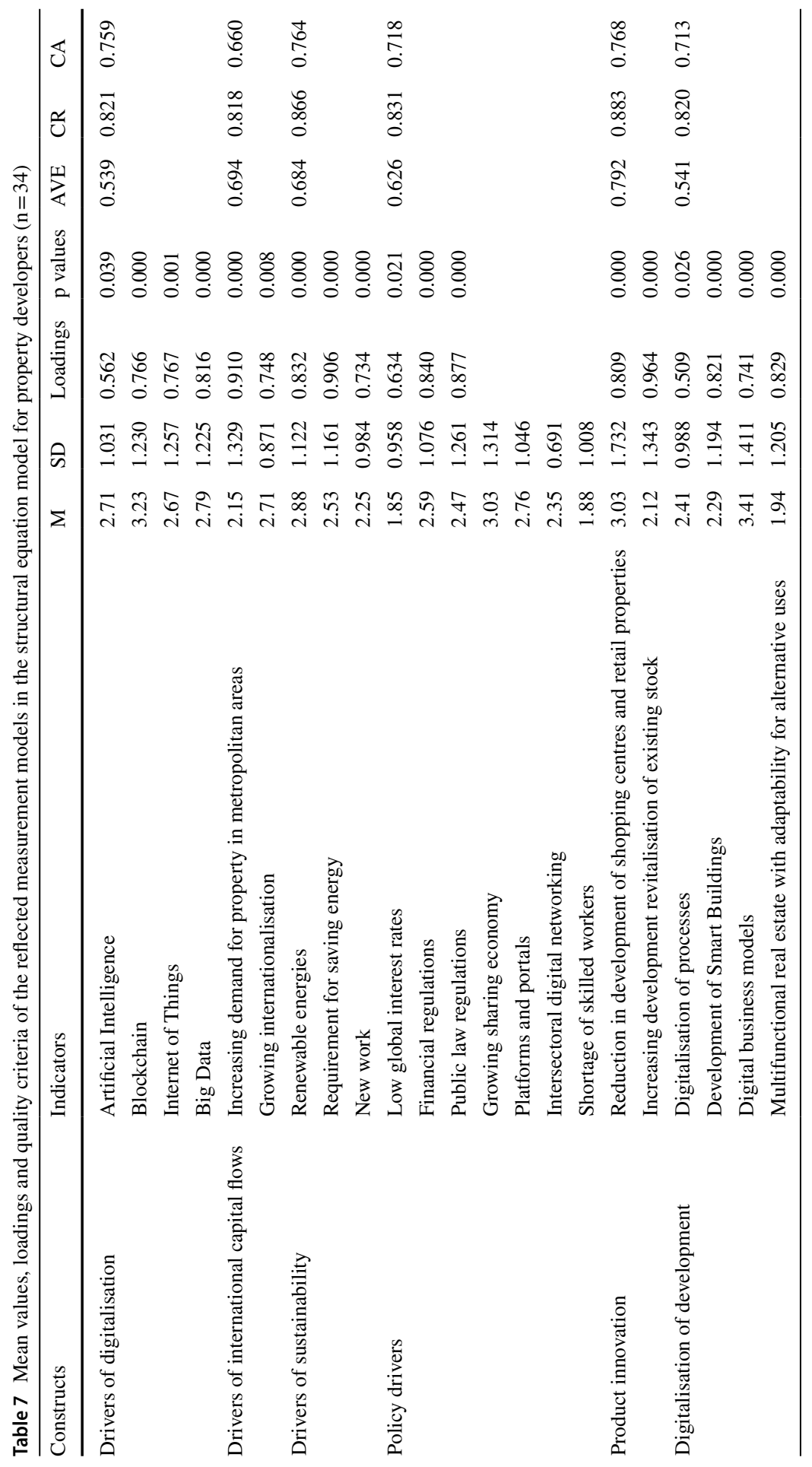




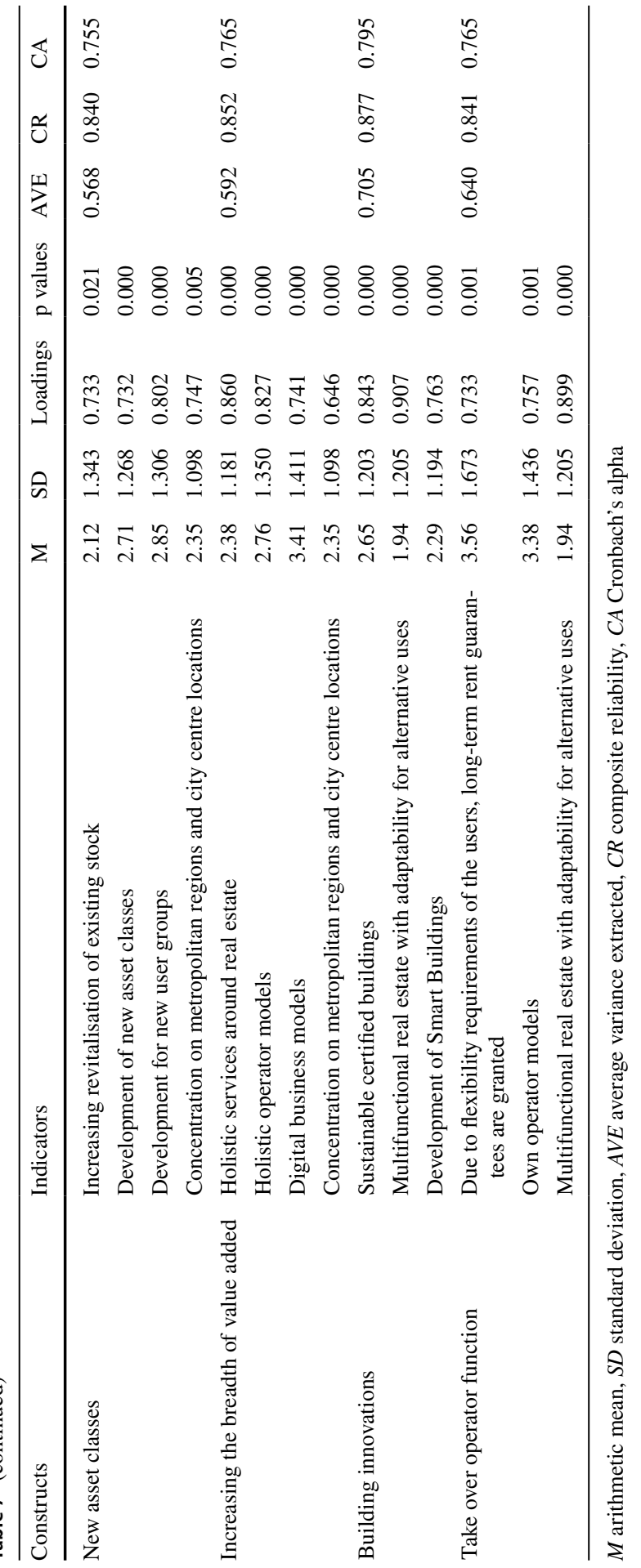




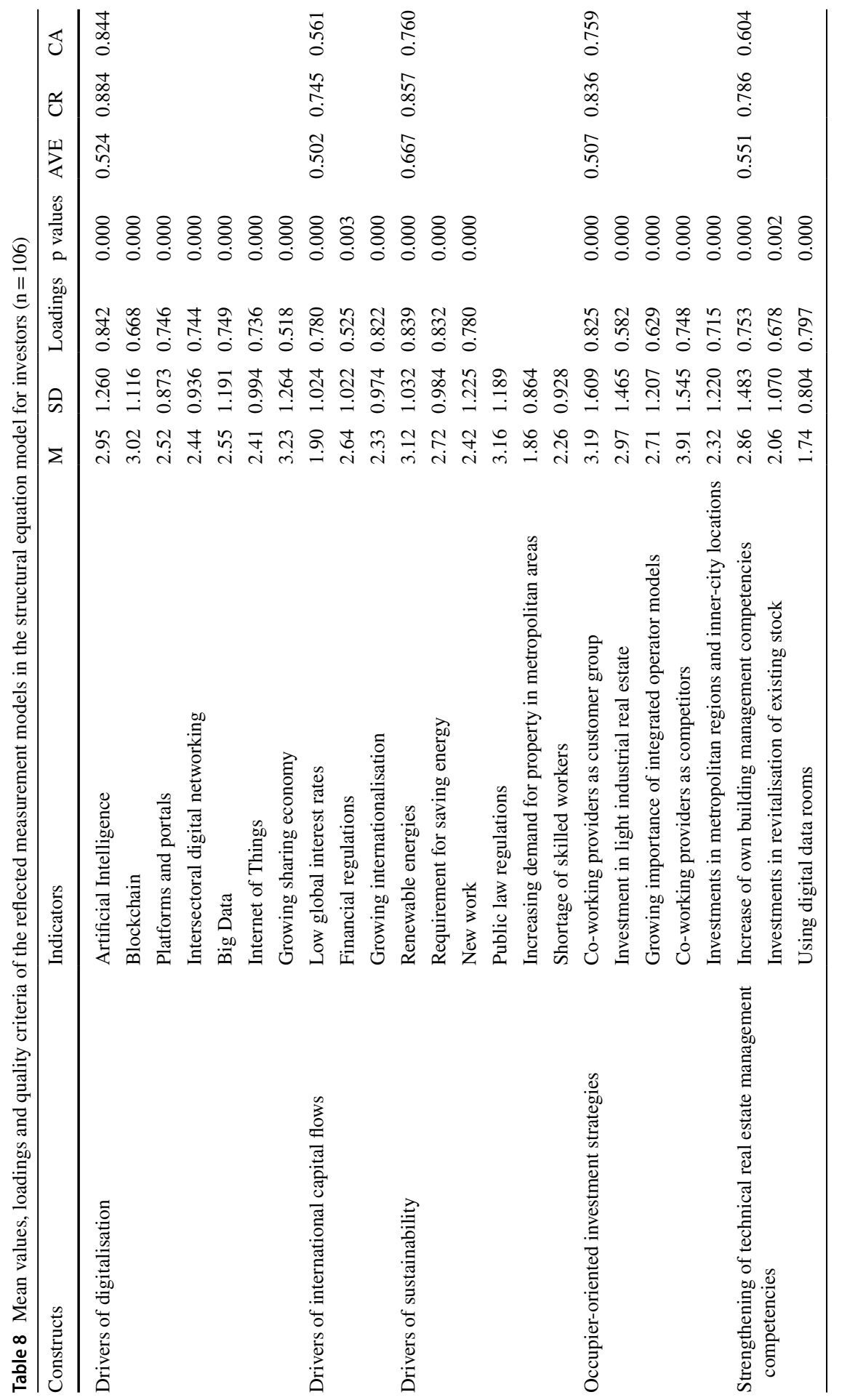




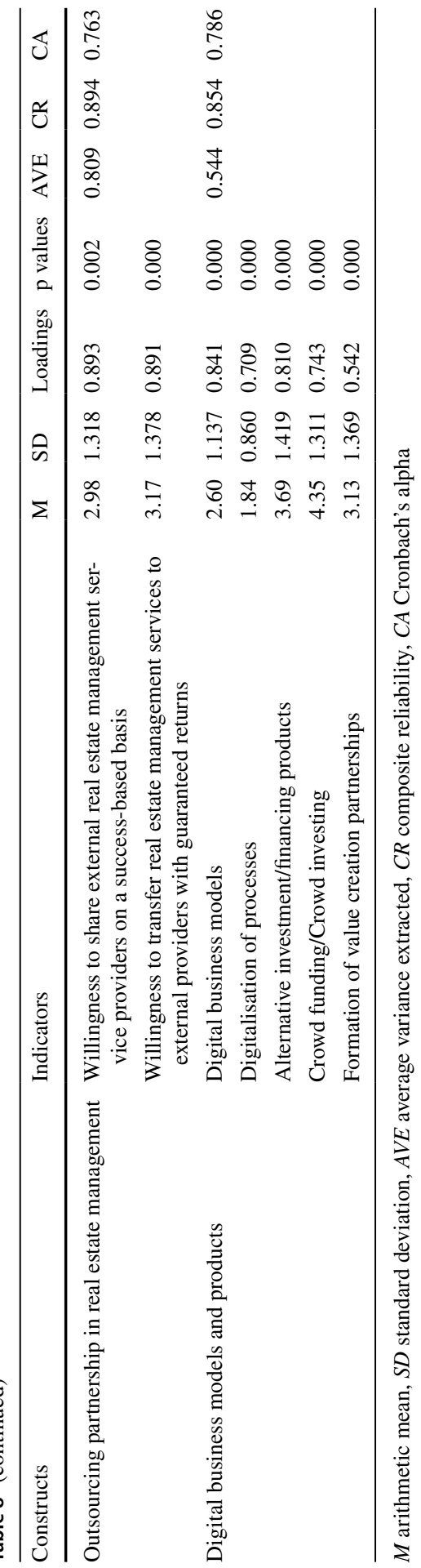




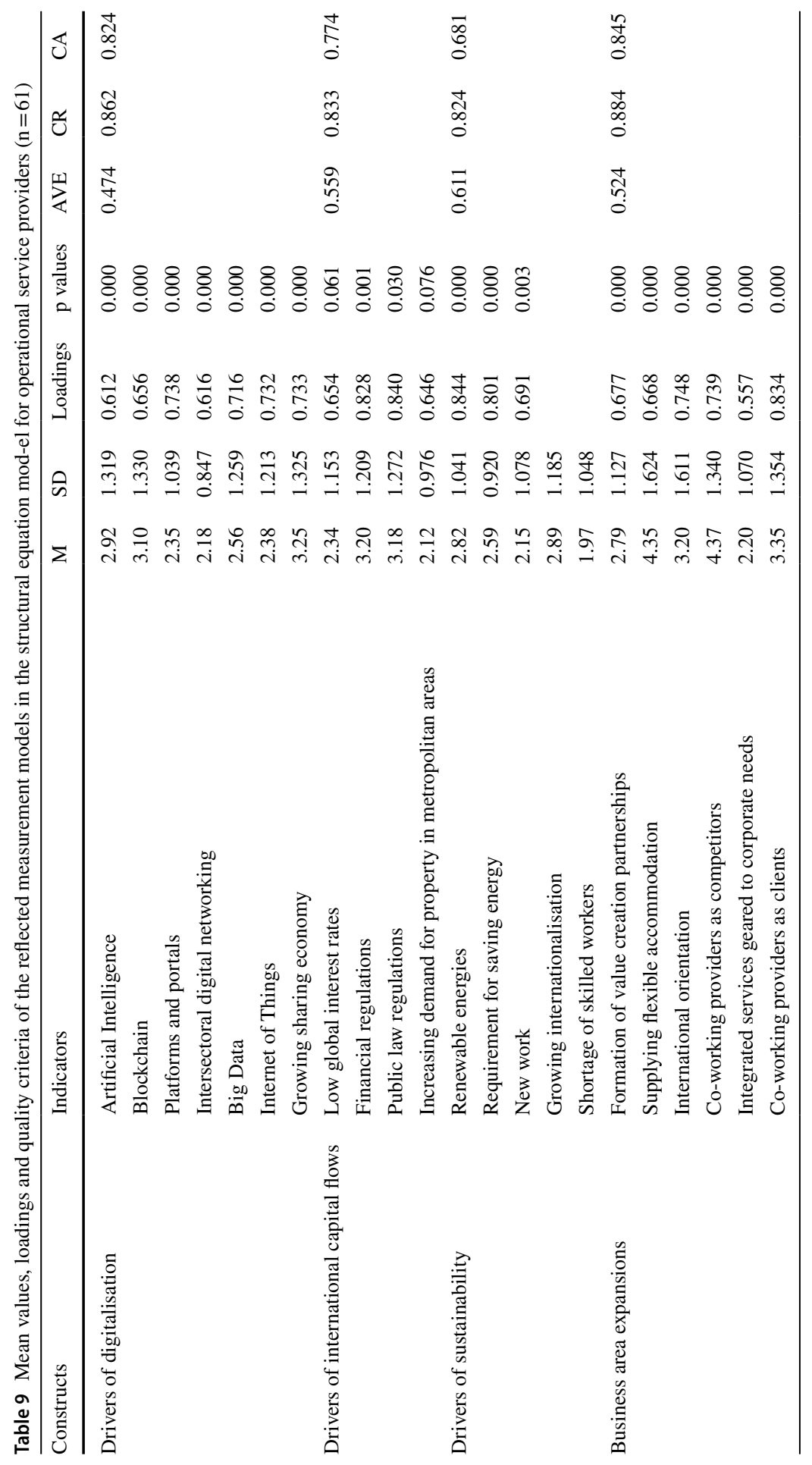




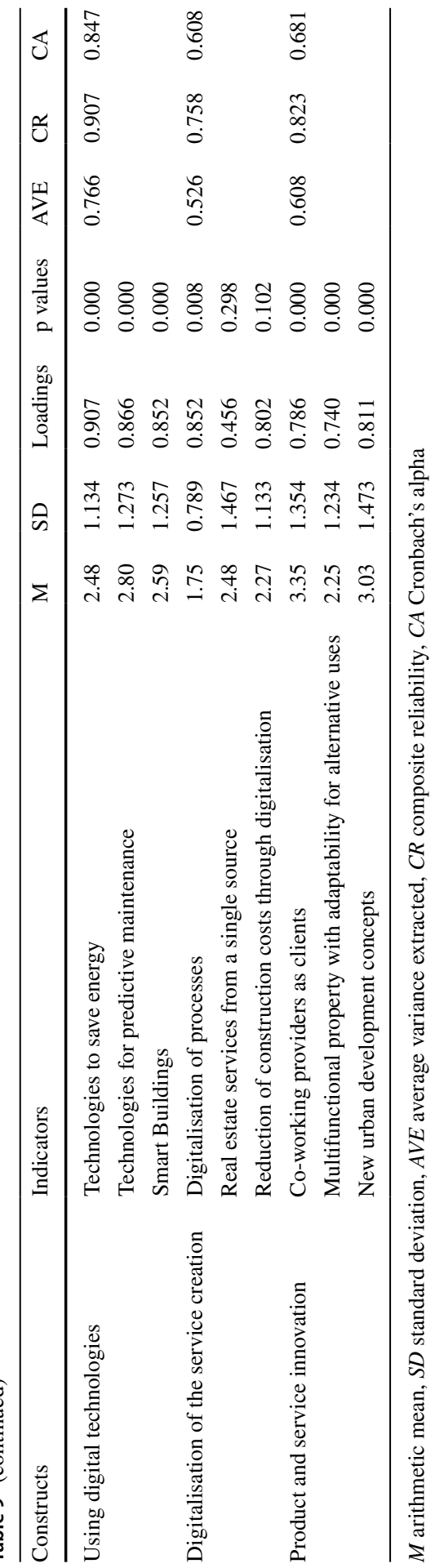




\section{References}

Aghion P, Howitt P (1990) A model of growth through creative destruction. NBER Working Paper No. 3223. https://doi.org/10.3386/w3223

Aldrich HE, Pfeffer J (1976) Environments of organizations. Annu Rev Sociol 2(1):79-105. https://doi. org/10.1146/annurev.so.02.080176.000455

Alexiev AS, Volberda HW, van den Bosch FAJ (2016) Interorganizational collaboration and firm innovativeness: unpacking the role of the organizational environment. J Bus Res 69(2):974-984. https:// doi.org/10.1016/j.jbusres.2015.09.002

Ansoff HI (1975) Managing strategic surprise by response to weak signals. Calif Manag Rev 18(2):2133. https://doi.org/10.2307/41164635

Appio FP, De Luca LM, Morgan RE, Martini A (2019) Patent portfolio diversity and firm profitability: a question of specialization or diversification? J Bus Res 101:255-267. https://doi.org/10.1016/j. jbusres.2019.04.020

Armstrong SJ, Overton TS (1977) Estimating nonresponse bias in mail surveys. J Mark Res 14(3):396402. https://doi.org/10.2307/3150783

Bagozzi RP, Yi Y (2012) Specification, evaluation, and interpretation of structural equation models. J Acad Mark Sci 40(1):8-34. https://doi.org/10.1007/s11747-011-0278-X

Bart IL (2010) Urban sprawl and climate change: a statistical exploration of cause and effect, with policy options for the EU. Land Use Policy 27(2):283-292. https://doi.org/10.1016/j.landusepol .2009.03.003

Baumanns T, Freber P-S, Schober K-S, Kichner F (2016) Bauwirtschaft im Wandel-trends und Potenziale bis 2020. Studie Roland Berger GmbH \& UniCredit Bank AG, München

Blind K, Cremers K, Mueller E (2009) The influence of strategic patenting on companies' patent portfolios. Res Policy 38(2):428-436. https://doi.org/10.1016/j.respol.2008.12.003

Bölting T, Königsmann T, Neitzel M (2016) Digitalisierung in der Immobilienwirtschaft-Chancen und Risiken. InWIS-Studie in Kooperation mit der EBZ Business School, Bochum

Brounen D, Eichholtz P (2004) Demographics and the global office market-consequences for property portfolios. J Portf Manag 10(3):231-242

Brown SL, Eisenhardt KM (1998) Competing on the edge: strategy as structured chaos. Long Range Plan 31(5):786-789. https://doi.org/10.1016/S0024-6301(98)00092-2

Buliga O, Scheiner CW, Voigt K-I (2016) Business model innovation and organizational resilience: towards an integrated conceptual framework. J Bus Econ 86(6):647-670. https://doi.org/10.1007/ s11573-015-0796-y

Bundesinstitut für Bau-, Stadt- und Raumforschung (BBSR) im Bundesamt für Bauwesen und Raumordnung (BBR) (2019) Nachdenken über die Stadt von übermorgen. BBSR-Online-Publikation Nr. $11 / 2019$, Bonn

Busch R, Dögl R, Unger F (2013) Integriertes marketing: Strategie, Organisation, Instrumente. Springer, Wiesbaden

Chin WW, Newsted PR (1999) Structural equation modeling analysis with small samples using partial least squares. In: Hoyle RH (ed) Statistical strategies for small sample research. Sage, Thousand Oaks, pp 334-342

Clark C (1940) The conditions of economic progress. Macmillan and co. limited, London

Cohen WM (2010) Fifty years of empirical studies of innovative activity and performance. Handb Econ Innov 1:129-213. https://doi.org/10.1016/S0169-7218(10)01004-X

Cook D (2015) RICS futures: turning disruption from technology to opportunity. J Prop Invest Financ 33(5):456-464. https://doi.org/10.1108/JPIF-05-2015-0039

Currit N, Easterling WE (2009) Globalization and population drivers of rural-urban land-use change in Chihuahua, Mexico. Land Use Policy 26(3):535-544. https://doi.org/10.1016/j.landusepol .2008.08.001

Damanpour F (1991) Organizational innovation: a meta-analysis of effects of determinants and moderators. Acad Manag J 34(3):555-590. https://doi.org/10.5465/256406

Deckers R, Heinemann G (2008) Trends erkennen-Zukunft gestalten, vom Zukunftswissen zum Markterfolg. Business Village $\mathrm{GmbH}$, Göttingen

Deng X, Huang J, Rozelle S, Zhang J, Li Z (2015) Impact of urbanization on cultivated land changes in China. Land Use Policy 45:1-7. https://doi.org/10.1016/j.landusepol.2015.01.007 
Deschermeier P, Voigtländer M (2017) Auswirkungen des demografischen Wandels auf die Büroimmobilienmärkte in Deutschland. IW-Trends-Vierteljahresschrift zur empirischen Wirtschaftsforschung. Institut der deutschen Wirtschaft (IW) 44(4):39-55

Deutsche Bauindustrie (2018) Bauindustrie zu den Konjunkturindikatoren im Oktober 2018: Goldener Oktober am Bau. https://www.bauindustrie.de/presse/presseinformationen/bauindustrie-zu-denkonjunkturindikatoren-im-oktober-2018-goldener-oktober-am-bau/. Accessed 27 Dec 2018

Diamantopoulos A, Winklhofer HM (2001) Index construction with formative indicators: an alternative to scale development. J Mark Res 38(2):269-277. https://doi.org/10.1509/ jmkr.38.2.269.18845

Diller H, Lorch K (1984) Strukturwandel als Herausforderung für die Wirtschafts- und Unternehmenspolitik. In: Diller H (ed) Strukturwandel, innovative Unternehmenspolitik und Strukturreformen in der öffentlichen Verwaltung. Schriften des Fachbereichs Wirtschafts- und Organisationswissenschaften der Hochschule der Bundeswehr Hamburg, Band 7. Heymanns Verlag KG, Berlin/Bonn/München, pp 7-38

Dyllick T (1989) Management der Umweltbeziehungen: Öffentliche Auseinandersetzung als Herausforderung. Gabler, Wiesbaden. https://doi.org/10.1007/978-3-663-12228-9

Falkenbach H, Toivonen S (2010) Effects of international investments on the finnish commercial real estate market. J Real Estate Lit 18(2):313-328. https://doi.org/10.5555/reli.18.2.g3g6334vjq 053208

Feld L, Schulten A, Jahn M, Simons H (2017) Frühjahrsgutachten Immobilienwirtschaft 2017 des Rates der Immobilienweisen. ZIA Zentraler Immobilien Ausschuss e.V, Berlin

Fisher AGB (1939) Production, primary, secondary and tertiary. Econ Rec 15(1):24-38. https://doi. org/10.1111/j.1475-4932.1939.tb01015.x

Gilbert R (2006) Looking for Mr Schumpeter: where are we in the competition-innovation debate? In: Jaffe A, Lerner J, Stern S (eds) Innovation policy and the economy, vol 6. NBER Books, Cambridge, pp 159-215

Gläser J, Laudel G (2010) Experteninterviews und qualitative Inhaltsanalyse. Springer, Wiesbaden

Gordon TJ, Glenn JC (2009) Environmental scanning. In: Glenn JC, Gordon TJ (ed) Futures research methodology, 3rd edn. The Millennium Project, pp i-59

Gupta A (2013) Environment and PEST analysis: an approach to external business environment. Int J Mod Soc Sci 2(1):34-43. https://pdfs.semanticscholar.org/d9d2/86c5a903a91d4e5e6cff565f1 86f91383a02.pdf

Hacklin F, Björkdahl J, Wallin MW (2018) Strategies for business model innovation: how firms reel in migrating value. Long Range Plan 51(1):82-110. https://doi.org/10.1016/j.1rp.2017.06.009

Hagemann H (2011) Wachstum und Strukturwandel. Wirtschaftspolitische Blätter 58(4):603-617

Hair JF, Ringle CM, Sarstedt M (2013) Partial least squares structural equation modeling: rigorous applications, better results and higher acceptance. Long Range Plan 46(1-2):1-12. https://doi. org/10.1016/j.lrp.2013.01.001

Hair JF, Hult TM, Ringle CM, Sarstedt M, Richter NF, Hauff S (2017) Partial least squares Strukturgleichungsmodellierung (PLS-SEM)—Eine anwendungsorientierte Einführung. Franz Vahlen $\mathrm{GmbH}$, München

Helmstädter V (1982) Ordnungsrechtliche Probleme der Strukturberichterstattung. In: Gahlen B (ed) Strukturberichterstattung der Wirtschaftsforschungsinstitute-analyse und Diskussion. J. C. B. Mohr, Tübingen, pp 52-67

Henseler J, Sarstedt M (2013) Goodness-of-fit indices for partial least squares path modeling. Comput Stat 28:565-580. https://doi.org/10.1007/s00180-012-0317-1

Henseler J, Dijkstra TK, Sarstedt M, Ringle CM, Diamantapoulos A, Straub DW et al (2014) Common beliefs and reality about PLS: comments on Rönkkö and Evermann (2013). Organ Res Methods 17(2):182-209. https://doi.org/10.1177/1094428114526928

Henseler J, Ringle CM, Sarstedt M (2015) A new criterion for assessing discriminant validity in variance-based structural equation modeling. J Acad Mark Sci 43:115-135. https://doi.org/10.1007/ s11747-014-0403-8

Homburg C, Pflesser C, Klarmann M (2008) Strukturgleichungsmodelle mit latenten Variablen: Kausalanalyse. In: Herrmann A, Homburg C, Klarmann M (eds) Handbuch Marktforschung: MethodenAnwendungen-Praxisbeispiele, 3rd edn. Gabler, Wiesbaden, pp 547-577

Hornsby JS, Kuratko DF, Shepherd DA, Bott JP (2009) Managers' corporate entrepreneurial actions: examining perception and position. J Bus Ventur 24(3):236-247. https://doi.org/10.1016/j.jbusv ent.2008.03.002 
Hügel S, Kreutzer M, Rottke NB (2019) Firm innovativeness in service industries: a construct validation in the external environment and industry structure context. Int J Innov Manag 23(6):1-57. https:// doi.org/10.1142/S1363919619500518

Jarvis CB, MacKenzie SB, Podsakoff PM (2003) A critical review of construct indicators and measurement model misspecification in marketing and consumer research. J Consum Res 30:199-218. https://doi.org/10.1086/376806

Jaworski B, Kohli AK, Sahay A (2000) Market-driven versus driving markets. J Acad Mark Sci 28(1):4554. https://doi.org/10.1177/0092070300281005

Just T (2013) Demografie und Immobilien, 2nd edn. Oldenbourg-Verlag, München

Just T (2017) Demografische trends als Bestimmungsfaktor für die Immobiliennachfrage. In: Rottke NB, Voigtländer M (eds) Immobilienwirtschaftslehre-Ökonomie. Springer, Wiesbaden, pp 871-901

Just T, Pfnür A, Braun C (2017a) Aurelis-Praxisstudie: Wie Corporates die Märkte und das Management für produktionsnahe Immobilien einschätzen. In: Pfnür A (ed), Arbeitspapiere zur immobilienwirtschaftlichen Forschung und Praxis, Band Nr. 31, Technische Universität Darmstadt

Just T, Voigtländer M, Eisfeld R, Henger R, Hesse M, Toschka A (2017b) Wirtschaftsfaktor Immobilien 2017. Gutachten für den Deutschen Verband für Wohnungswesen, Städtebau und Raumordnung e. V. und die Gesellschaft für Immobilienwirtschaftliche Forschung e. V. Germany, Europe: IREBS International Real Estate Business School, Universität Regensburg

Kjellberg H, Azimont F, Reid E (2015) Market innovation processes: balancing stability and change. Ind Mark Manage 44:4-12. https://doi.org/10.1016/j.indmarman.2014.10.002

Kroll F, Haase D (2010) Does demographic change affect land use patterns? A case study from Germany. Land Use Policy 27(3):726-737. https://doi.org/10.1016/j.landusepol.2009.10.001

Malerba F (2002) Sectoral systems of innovation and production. Res Policy 31(2):247-264. https://doi. org/10.1016/S0048-7333(01)00139-1

Mayer HO (2009) Interview und schriftliche Befragung: Entwicklung, Durchführung, Auswertung, 5th edn. Oldenbourg, München

Meyer K (2016) Immobilienbeschaffung durch lebenszyklusübergreifende Wertschöpfungspartnerschaften: Empirische Analyse der Chancen und Risiken betrieblicher Immobiliennutzer. Dissertation, Technische Universität Darmstadt

Miller D, Friesen PH (1982) Innovation in conservative and entrepreneurial firms: two models of strategic momentum. Strateg Manag J 3(1):1-25. https://doi.org/10.1002/smj.4250030102

Moring A, Maiwald L, Kewitz T (2018) Bits and Bricks: Digitalisierung von Geschäftsmodellen in der Immobilienbranche. Springer, Wiesbaden

Mühlroth C, Grottke M (2018) A systematic literature review of mining weak signals and trends for corporate foresight. J Bus Econ 88(5):643-687. https://doi.org/10.1007/s11573-018-0898-4

Müller A (2008) Strategic foresight-Prozesse strategischer Trend- und Zukunftsforschung in Unternehmen. Dissertation, University of St. Gallen

Müller-Stewens G, Müller A (2009) Strategic Foresight. Trend- und Zukunftsforschung als Strategieinstrument. In: Reimer M, Fiege S (eds) Perspektiven des Strategischen Controllings. Gabler/GWV Fachverlage GmbH, Wiesbaden, pp 239-257. http://doi.org/10.1007/978-3-8349-8805-8_15

Naisbitt J (1982) Megatrends, ten new directions transforming our lives. Warner Books, New York

Oertel CY, Markmann H, Brusgul J (2014) Digitalisierung in der Immobilienwirtschaft—Eine qualitative und quantitative Analyse der Bedeutung des Megatrends der Digitalisierung mit speziellem Fokus auf Einzelhandels- und Logistikimmobilien. In: Rottke NB (ed) EBS Diskussionspapiere zur Immobilienwirtschaft, No. 05, Wiesbaden

Peng GCA, Nunes MB (2007) Using PEST analysis as a tool for refining and focusing contexts for information system research. In: 6th european conference on research methodology for business and management studies, Lisbon, Portugal, pp 229-236

Pfnür A (2011) Modernes Immobilienmanagement. Immobilieninvestment, Immobiliennutzung, Immobilienentwicklung und -betrieb, 3rd edn. Springer, Berlin/Heidelberg

Pfnür A (2019) Herausforderungen des Corporate Real Estate Managements im Strukturwandel. Gutachten im Auftrag des Zentraler Immobilien Ausschuss ZIA e.V, Berlin

Pfnür A, Seger J (2017) Produktionsnahe Immobilien. Herausforderungen und Entwicklungsperspektiven aus Sicht von Corporates, Investoren und Dienstleistern. In: Pfnür, A (ed), Arbeitspapiere zur immobilienwirtschaftlichen Forschung und Praxis, Band Nr. 35, Technische Universität Darmstadt

Pfnür A, Wagner B (2018) Transformation der Immobilienwirtschaft-Eine empirische Studie deutscher immobilienwirtschaftlicher Akteure. In: Pfnür A (ed): Arbeitspapiere zur 
immobilienwirtschaftlichen Forschung und Praxis, Band Nr. 37, Technische Universität Darmstadt

Picot A (1981) Strukturwandel und Unternehmensstrategien, Teil 1. Wirtschaftswissenschaftliches Studium 11. Verlage Franz Vahlen \& C. H. Beck, München/Frankfurt, pp 527-532

Picot A (1990) Strukturwandel und Wettbewerbsdruck. Schmalenbachs Zeitschrift für betriebswirtschaftliche. Forschung 42(2):119-134. https://epub.ub.uni-muenchen.de/6831/1/6831.pdf

Podsakoff PM, MacKenzie SB, Lee J-Y, Podsakoff NP (2003) Common method biases in behavioral research: a critical review of the literature and recommended remedies. J Appl Psychol 88(5):879-903. https://doi.org/10.1037/0021-9010.88.5.879

Preacher KJ, Hayes AF (2008) Asymptotic and resampling strategies for assessing and comparing indirect effects in multiple mediator models. Behav Res Methods 40(3):879-891. https://doi. org/10.3758/BRM.40.3.879

Rattanaprichavej N (2014) Enhancing the real estate development concept of highest and best use: A PEST analysis approach. In: Proceedings of the international symposium on business and management (ISBM), Nagoya, Japan, 2014. https://ssrn.com/abstract=2420219

Rhee H-S, Ryu YU, Kim C-T (2012) Unrealistic optimism on information security management. Comput Secur 31:221-232. https://doi.org/10.1016/j.cose.2011.12.001

Rüegg-Stürm J (2002) Das neue St. Galler Management-Modell. Grundkategorien einer integrierten Managementlehre: Der HSG-Ansatz. Haupt, Bern/Stuttgart/Wien

Ruff F (2015) The advanced role of corporate foresight in innovation and strategic managementreflections on practical experiences from the automotive industry. Technol Forecast Soc Change 101:37-48. https://doi.org/10.1016/j.techfore.2014.07.013

Saiz A, Salazar A (2017) Real trends-the future of real estate in the United States. http://doi. org/10.2139/ssrn.3100934

Sampere JPV (2016) Why platform disruption is so much bigger than product disruption. Harvard Bus Rev

Schehl M (1993) Die Kostenrechnung der Industrieunternehmen vor dem Hintergrund unternehmensexterner und-interner Strukturwandlungen-Eine theoretische und empirische Untersuchung. Abhandlungen aus dem Industrieseminar der Universität Mannheim, Heft 40. Duncker \& Humblot, Berlin

Scherer FM, Ross D (1990) Industrial market structure and economic performance, 3rd edn. Houghton Mifflin Company, Bosten

Schmidiger M, Kovacic I, Petzold F, Volm JM (2017) Digitalisierungsbarometer 2017-Die Immobilienbranche im digitalen Wandel. Verlag IFZ-Hochschule, Luzern/Zug

Schumpeter J (1928) The instability of capitalism. Econ J 38(151):361-386. https://doi. org/10.2307/2224315

Sears GJ, Baba VV (2011) Toward a multistage, multilevel theory of innovation. Can J Adm Sci 28:357-372. https://doi.org/10.1002/cjas.198

Staub P, Stucki M, Wettstein A (2016) Digital real estate: Bedeutung und Potenziale der Digitalisierung für die Akteure der Immobilienwirtschaft. SVIT Verlag AG, Zürich

Streissler E (1982) Theorie der Wirtschaftsstruktur: Was ist Gegenstand der Strukturberichterstattung? In: Gahlen B (ed) Strukturberichterstattung der Wirtschaftsforschungsinstitute-Analyse und Diskussion. J. C. B. Mohr, Tübingen, pp 1-27

Tidd J (2001) Innovation management in context: environment, organization and performance. Int J Manag Rev 3(3):169-183. https://doi.org/10.1111/1468-2370.00062

Toivonen S, Viitanen K (2015) Forces of change shaping the future commercial real estate market in the Helsinki Metropolitan Area in Finland. Land Use Policy 42:471-478. https://doi.org/10.1016/j. landusepol.2014.09.004

Toivonen S, Viitanen K (2016) Environmental scanning and futures wheels as tools to analyze the possible future themes of the commercial real estate market. Land Use Policy 52:51-61. https://doi. org/10.1016/j.landusepol.2015.12.011

Ulrich H (1970) Die Unternehmung als produktives soziales System-Grundlagen der allgemeinen Unternehmungslehre. Schriftenreihe Unternehmung und Unternehmensführung, Herausgegeben vom Institut für Betriebswirtschaft an der Hochschule St. Gallen. 2nd edn. Paul Haupt, Bern/ Stuttgart

Vance A, Siponen M, Pahnila S (2012) Motivating is security compliance: insights from Habit and Protection Motivation Theory. Inf Manag 49:190-198. https://doi.org/10.1016/j.im.2012.04.002

Vejlgaard H (2008) Anatomy of a trend. McGraw-Hill, New York 
Veugelers M, Bury J, Viaene S (2010) Linking technology intelligence to open innovation. Technol Forecast Soc Change 77(2):335-343. https://doi.org/10.1016/j.techfore.2009.09.003

von der Gracht HA, Vennemann CR, Darkow IL (2010) Corporate foresight and innovation management: a portfolio-approach in evaluating organizational development. Futures 42(4):380-393. https://doi. org/10.1016/j.futures.2009.11.023

von Groddeck V, Schwarz JO (2013) Perceiving megatrends as empty signifiers: a discourse-theoretical interpretation of trend management. Futures 47:28-37. https://doi.org/10.1016/j.futur es.2013.01.004

Vongpraseuth T, Choi CG (2015) Globalization, foreign direct investment, and urban growth management: policies and conflicts in Vientiane, Laos. Land Use Policy 42:790-799. https://doi. org/10.1016/j.landusepol.2014.10.003

Vornholz G (2017) Entwicklungen und Megatrends der Immobilienwirtschaft, 3rd edn. De Gruyter Oldenbourg, Berlin/Boston

Weber V (2017) Digitale Transformation und Innovation in der deutschen Immobilienbranche 2017. CBRE Research and Future Real Estate Institute: Frankfurt/Regensburg

Wijburg G, Aalbers MB (2017) The internationalization of commercial real estate markets in France and Germany. Comput Change 21(4):301-320. https://doi.org/10.1177/1024529417712040

Wong KK-K (2013) Partial least squares structural equation modeling (PLS-SEM) techniques using SmartPLS. Mark Bull 24(1):1-32. https://doi.org/10.1108/EBR-10-2013-0128

Yoo Y, Henfridsson O, Lyytinen K (2010) The new organizing logic of digital innovation: an agenda for information systems research. Inf Syst Res 21(4):724-735. https://doi.org/10.1287/isre.1100.0322

Zeitner R, Peyinghaus M (2014) Megatrends und ihr Einfluss auf die Immobilienwirtschaft. Process Management Real Estate Monitor. Hochschule für Technik und Wirtschaft Berlin \& pom + international GmbH, Berlin/Frankfurt am Main

Zhang T (2001) Community features and urban sprawl: the case of the Chicago metropolitan region. Land Use Policy 18(3):221-232. https://doi.org/10.1016/S0264-8377(01)00018-7

Publisher's Note Springer Nature remains neutral with regard to jurisdictional claims in published maps and institutional affiliations. 